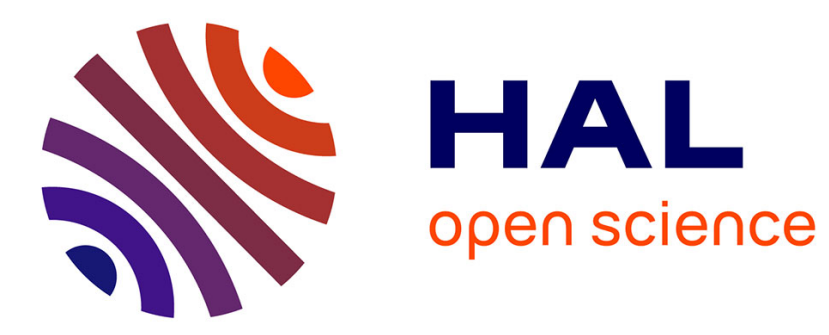

\title{
The Use of Domino Reactions for the Synthesis of Chiral Rings
}

Helene Pellissier

\section{To cite this version:}

Helene Pellissier. The Use of Domino Reactions for the Synthesis of Chiral Rings. Synthesis: Journal of Synthetic Organic Chemistry, 2020, 10.1055/s-0040-1707905 . hal-02988822

\section{HAL Id: hal-02988822 \\ https://hal.science/hal-02988822}

Submitted on 6 Nov 2020

HAL is a multi-disciplinary open access archive for the deposit and dissemination of scientific research documents, whether they are published or not. The documents may come from teaching and research institutions in France or abroad, or from public or private research centers.
L'archive ouverte pluridisciplinaire HAL, est destinée au dépôt et à la diffusion de documents scientifiques de niveau recherche, publiés ou non, émanant des établissements d'enseignement et de recherche français ou étrangers, des laboratoires publics ou privés. 


\section{The Use of Domino Reactions for the Synthesis of Chiral Rings}

Hélène Pellissier

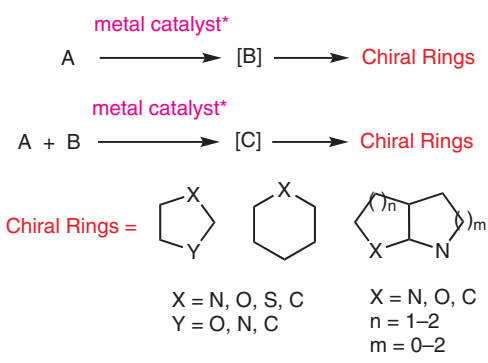

\section{Introduction}

In the last decades, asymmetric metal catalysis ${ }^{1}$ has been intensively combined with various types of domino reactions ${ }^{2}$ to give simple and economic access to many highly functionalized and complex chiral molecules. ${ }^{3}$ The goal of this short review is to highlight the advances made on the use of domino reactions catalyzed by chiral metals to synthesize chiral rings published in the last four years. It is divided into five parts, outlining successively the formation of one ring containing one nitrogen atom, one ring containing one oxygen/sulfur atom, one ring containing several heterocyclic atoms, one carbon ring, and two rings through enantioselective metal-catalyzed domino reactions.

\section{Formation of One Ring Containing One Nitrogen Atom}

\subsection{Five-Membered Rings}

Many densely functionalized chiral cyclic molecules have been easily synthesized through a variety of highly efficient enantioselective metal-catalyzed domino reactions. The frameworks of a wide range of natural products contain a five-membered ring. ${ }^{4}$ Chiral silver complexes have been shown to efficiently catalyze various types of domino reactions. ${ }^{5}$ For example, in 2016, Oh and co-workers described the synthesis of chiral pyrrolidines 3 based on the reaction of $\alpha, \beta$-unsaturated ketones $\mathbf{1}$ with imino esters $\mathbf{2}$ catalyzed by a catalyst system composed of AgF and chiral 1,2-diol ligand $4 .^{6}$ The chiral five-membered products 3 were obtained from successive Michael and Mannich reactions with complete diastereoselectivity ( $>99 \%$ de), good to quantitative yields (50-99\%) and variable enantioselectivities (22$98 \%$ ee) (Scheme 1). In the possible transition state depicted in Scheme 1, the silver atom coordinates the two ligands through the $\mathrm{N}-19$ tertiary amine. 


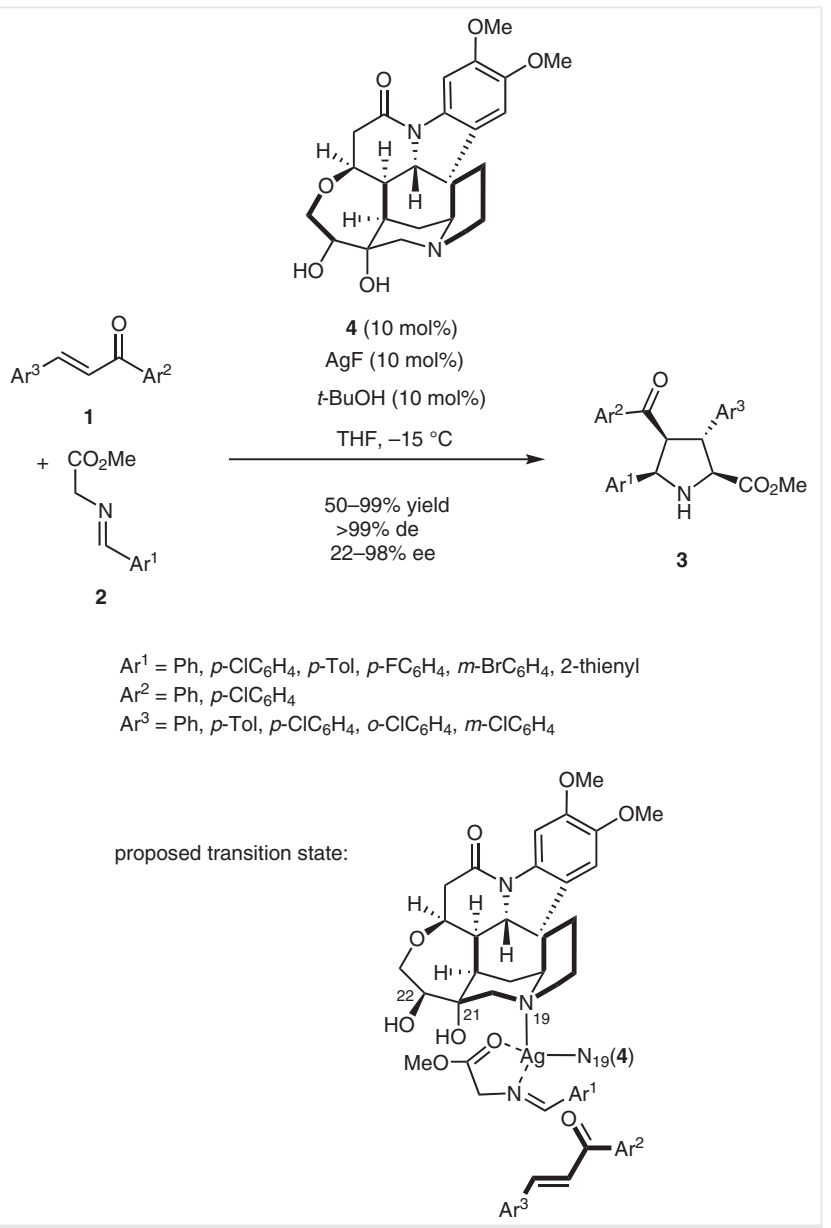

Scheme 1 Synthesis of pyrrolidines through an Ag-catalyzed domino reaction

In 2016, Fukuzawa et al. employed an alternative chiral silver complex derived from AgOAc and ferrocenyl chiral ligand $\mathbf{5}$ to promote asymmetric domino reactions between imino esters $\mathbf{2} / \mathbf{7}$ and nitroalkenes $\mathbf{6}^{7}$ As illustrated in Scheme 2, chiral pyrrolidines $\mathbf{8}$ were obtained in good yields (47-86\%), diastereoselectivities (76-92\% de) and enantioselectivities (86-97\% ee) from sequential Michael and aza-Henry reactions.

Chiral bicyclic pyrrolidines 12 were synthesized in 2016 by Wang et al. through domino reactions of imino esters 9 with $\mathrm{N}$-(2-t-butylphenyl)maleimide (10) using a combination of AgOAc and chiral phosphine ligand $\mathbf{1 1}$ as the catalyst system (Scheme 3). ${ }^{8}$ Products 12, arising from a Michael addition followed by a Mannich reaction, were obtained in homogeneous high yields (86-99\%), diastereoselectivities (>90\% de) and enantioselectivities (90 to >99\% ee).

Similar reactions were also investigated in 2016 by Xia and $\mathrm{Xu}$ in the presence of another catalyst system composed of AgF and Xing-Phos ligand. ${ }^{9}$ In this case, the reaction of $\mathrm{N}$-arylmaleimides $\mathbf{1 3}$ with aromatic imino esters $\mathbf{2}$

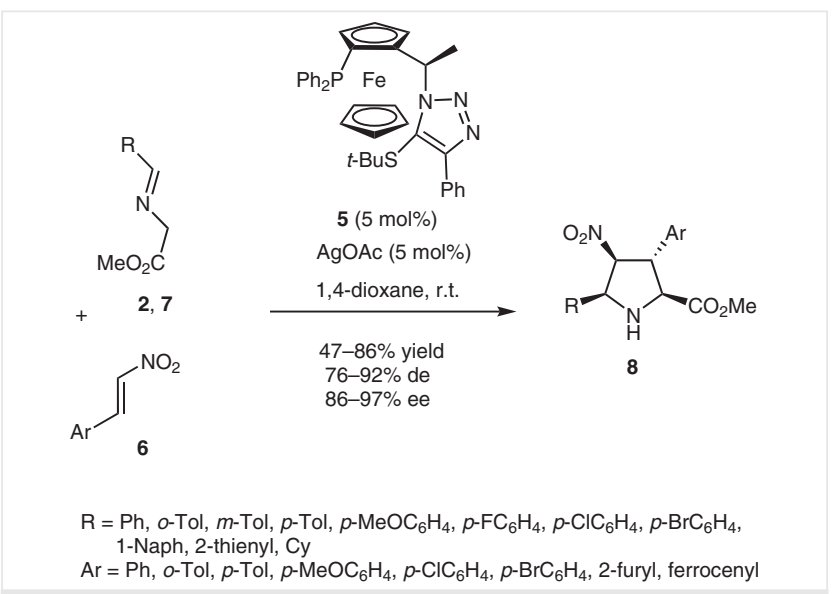

Scheme 2 Synthesis of pyrrolidines through an Ag-catalyzed domino reaction

or $\mathbf{1 4}$ afforded the corresponding bicyclic pyrrolidines $\mathbf{1 5}$ as single diastereomers (>96\% de) in high yields (83-99\%) and enantioselectivities (65-98\% ee) (Scheme 4).

Along with chiral silver catalysts, various chiral cobalt complexes have also been recently investigated as promoters in domino reactions. The use of cobalt catalysts is advantageous because of their low toxicity, their low cost and their ability to adopt various reaction pathways. ${ }^{10}$ For example, a chiral cobalt catalyst generated in situ from $\mathrm{Co}(\mathrm{acac})_{2}$ and chiral biphosphine ligand $\mathbf{1 6}$ was employed in 2017 by Ge et al. in the synthesis of enantiopure pyrrolidine 18 through the domino reaction of nitrogen-tethered 1,6-enyne 17 with pinacolborane (Scheme 5). ${ }^{11}$ The process involved an anti-Markovnikov hydroboration followed by a cyclization.

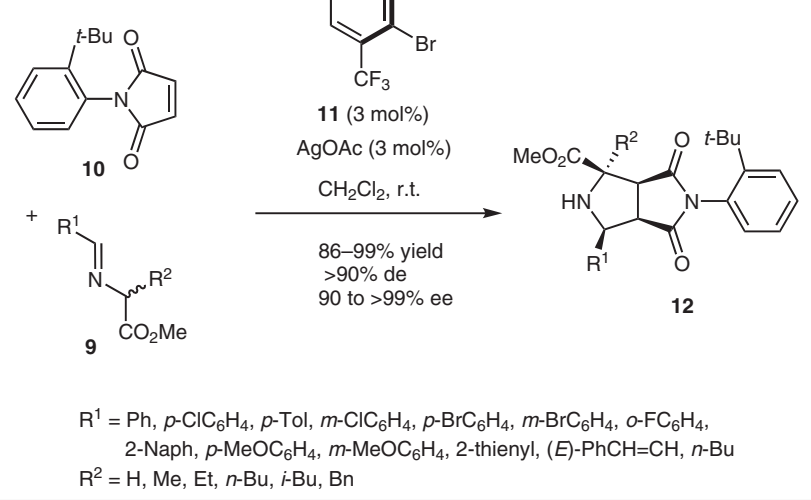

Scheme 3 Synthesis of bicyclic pyrrolidines through an Ag-catalyzed domino reaction 


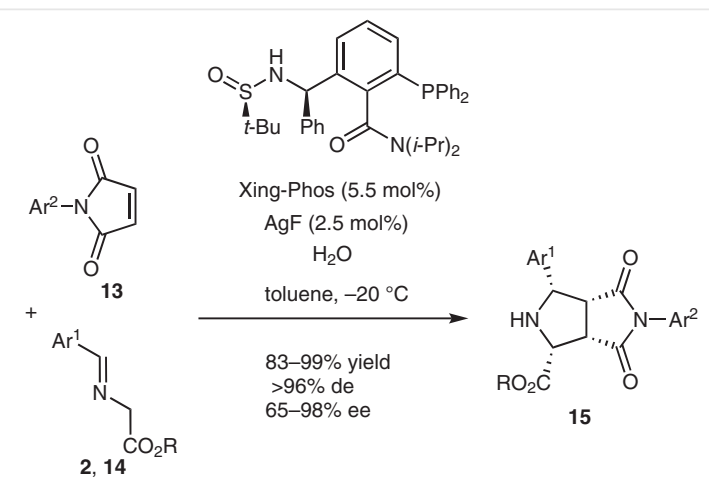

$\mathrm{Ar}^{1}=\mathrm{Ph}, o-\mathrm{MeOC}_{6} \mathrm{H}_{4}, m-\mathrm{MeOC}_{6} \mathrm{H}_{4}, m-\mathrm{BrC}_{6} \mathrm{H}_{4}, p-\mathrm{Tol}, p-\mathrm{FC}_{6} \mathrm{H}_{4}, p-\mathrm{ClC}_{6} \mathrm{H}_{4}$, $p-\mathrm{BrC}_{6} \mathrm{H}_{4}, p-\mathrm{PhC}_{6} \mathrm{H}_{4}, p-\mathrm{MeSC}_{6} \mathrm{H}_{4}, 3,5-\left(\mathrm{F}_{3} \mathrm{C}\right)_{2} \mathrm{C}_{6} \mathrm{H}_{3}$

$\mathrm{Ar}^{2}=\mathrm{Ph}, m-\mathrm{ClC}_{6} \mathrm{H}_{4}, m-\mathrm{Tol}, m-\mathrm{BrC}_{6} \mathrm{H}_{4}, p-\mathrm{EtOC}_{6} \mathrm{H}_{4}, p-\mathrm{MeOC}_{6} \mathrm{H}_{4}$, p- $-\mathrm{BrC}_{6} \mathrm{H}_{4}, 3,5-\mathrm{Me}_{2} \mathrm{C}_{6} \mathrm{H}_{3}$

$$
\mathrm{R}=\mathrm{Me}, \mathrm{Et}
$$

Scheme 4 Synthesis of other bicyclic pyrrolidines through an Ag-catalyzed domino reaction

$$
\begin{aligned}
& \overbrace{\mathrm{N}^{2}}^{N_{\mathrm{P}}^{\mathrm{i}}-\mathrm{Bu}} \\
& 16 \text { (4 mol\%) }
\end{aligned}
$$
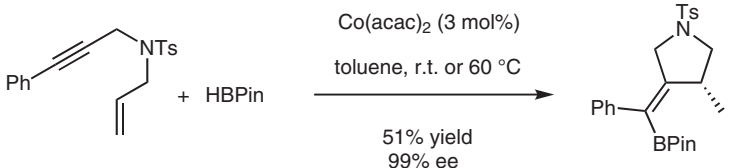

Scheme 5 Synthesis of pyrrolidine $\mathbf{1 8}$ through a Co-catalyzed domino reaction

While using chiral ligand $\mathbf{1 6}$ resulted in an antiMarkovnikov hydroboration of the alkyne moiety of substrate $\mathbf{1 7}$ (Scheme 5), the same authors showed that the involvement of chiral ligand $\mathbf{1 9}$ combined with the same precatalyst led to chiral pyrrolidine $\mathbf{2 0}$ with $92 \%$ ee and $66 \%$ yield, arising from a Markovnikov hydroboration of the alkyne group of the nitrogen-tethered 1,6-enyne 17 with pinacolborane (Scheme 6). ${ }^{11}$

In 2018, Fan et al. developed an unprecedented synthesis of chiral 3,4-dimethylene-pyrrolidines possessing an oxa/azabenzonorbornadiene moiety based on the asymmetric domino reaction of oxa/azabenzonorbornadienes $\mathbf{2 1}$ with 1,6-enynes $\mathbf{2 2} .^{12}$ The process, employing a catalyst system composed of $\left[\mathrm{Rh}(\operatorname{cod})_{2}\right] \mathrm{BF}_{4}$ and chiral diphosphine ligand $(R)$-An-SDP, provided enantiopure (97-99\% ee) 3,4-dimethylene-pyrrolidines 23 in good yields (44-89\%). A possible mechanism for the reaction is depicted in Scheme 7. Complex 24, arising from the coordination of the rhodium catalyst to 1,6-enyne $\mathbf{2 2}$, underwent a cyclization to afford intermediate 25. Next, a $\beta$-hydride elimination led to intermediate $\mathbf{2 6}$ that coordinates to substrate $\mathbf{2 1}$ to give inter- mediate 27. Subsequent insertion of the alkene into the Rh$\mathrm{C}$ bond led to intermediate $\mathbf{2 8}$, which finally delivered product 23.

Palladium has been previously applied to promote many enantioselective domino transformations. ${ }^{13}$ In 2017 , Jia et al. employed asymmetric palladium catalysis to develop a method for the synthesis of chiral 2,3-disubstituted indolines 32. ${ }^{14}$ The process involved the reaction between indoles $\mathbf{2 9}$ and terminal alkynes $\mathbf{3 0}$ promoted by a chiral palladium catalyst derived from $\mathrm{Pd}(\mathrm{dba})_{2}$ and chiral phosphoramidite ligand 31. Complex molecules 32 were obtained through consecutive Heck and Sonogashira reactions as almost single diastereomers ( $>90 \%$ de) with high enantioselectivities (79-94\% ee) and good yields (50-93\%) (Scheme 8).

Chiral nickel catalysts ${ }^{15}$ have also been successfully applied to promote enantioselective domino processes. ${ }^{16}$ For example, the synthesis of chiral bis-heterocycles 35 was developed by Kong et al. in 2018 through enantioselective nickel-catalyzed domino reactions of alkenes $\mathbf{3 3}$ with aryl bromides 34. ${ }^{17}$ As presented in Scheme 9, the reactions proceeded with excellent enantioselectivities (94-98\% ee), affording the products in good yields $(40-81 \%)$. The process employed a combination of $\mathrm{Ni}(\operatorname{cod})_{2}$ and chiral ferrocenyl phosphine ligand $\mathbf{3 6}$ as the catalyst system leading to a cyclization followed by a cross-coupling reaction.

In 2018, Feng and Liu reported an example of bimetallic relay catalysis applied to the synthesis of chiral 2,2,3-trisubstituted indolines. ${ }^{18}$ As shown in Scheme 10, the catalyst system consisted of a combination of $\mathrm{Sc}(\mathrm{OTf})_{3}$, chiral $N, N^{\prime}$-dioxide ligand 37 and $\mathrm{Rh}_{2}(\mathrm{OAc})_{4}$, which promoted the intramolecular trapping of ammonium ylides generated from $\alpha$-diazoketones 38 and 2-aminophenyl-substituted $\alpha, \beta$-unsaturated ketones 39. This domino process yielded a range of chiral indolines $\mathbf{4 0}$ as single diastereomers ( $>90 \%$ de) in good to excellent yields (66-99\%) and enantioselectivities (73-99\% ee).

Later, in 2019, the same authors employed related chiral $N, N^{\prime}$-dioxide ligand 41 combined with $\mathrm{Mg}(\mathrm{OTf})_{2}$ to promote

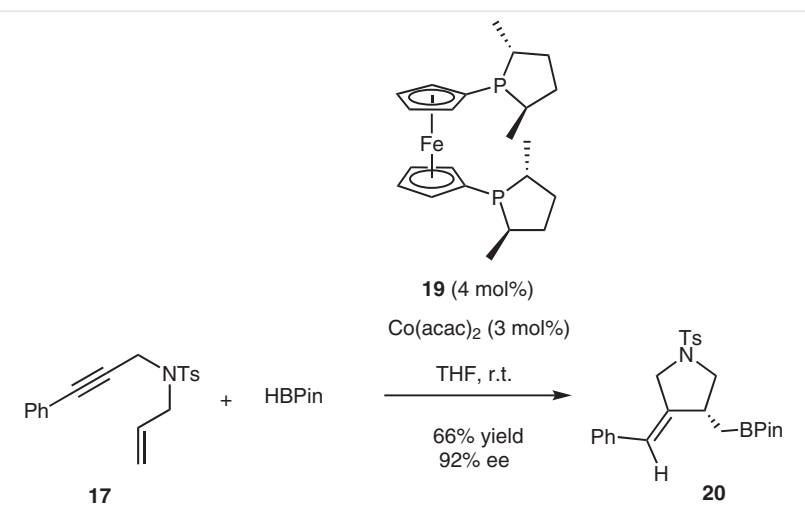

Scheme 6 Synthesis of pyrrolidine 20 through a Co-catalyzed domino reaction 


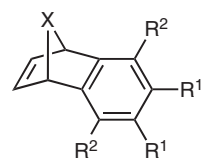

21<smiles>[Y]N([CH2+])CC#C</smiles>

22

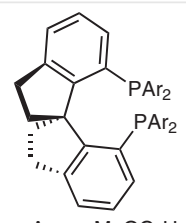

$\mathrm{Ar}=p-\mathrm{MeOC}_{6} \mathrm{H}_{4}$ (R)-An-SDP (6.5 mol\%) $\left[\mathrm{Rh}(\mathrm{cod})_{2}\right] \mathrm{BF}_{4}(5 \mathrm{~mol} \%)$

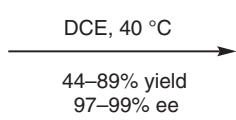

$\mathrm{R}^{1}=\mathrm{H}, \mathrm{Me}, \mathrm{OMe}, \mathrm{Br}$

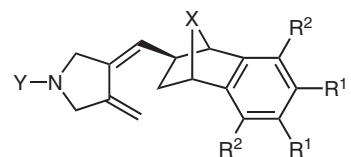

23

$\mathrm{R}^{1}-\mathrm{R}^{1}=\mathrm{OCH}_{2} \mathrm{O}, \mathrm{O}\left(\mathrm{CH}_{2}\right)_{2} \mathrm{O}$

$\mathrm{R}^{2}=\mathrm{H}, \mathrm{OMe}$

$\mathrm{Y}=\mathrm{Ts}, \mathrm{Boc}, \mathrm{Ns}, \mathrm{SO}_{2} \mathrm{Ph}$

$\mathrm{X}=\mathrm{NBoc}, \mathrm{NT}$ s

proposed mechanism:<smiles>[R]c1c([R])c([R])c2c(c1[R])C1CCC(/C=C3/CN([Al])CC3=C)C2C1[X]</smiles>

$\left[\mathrm{Rh}(\operatorname{cod})_{2}\right] \mathrm{BF}_{4}+(R)-\mathrm{An}-\mathrm{SDP}$

23

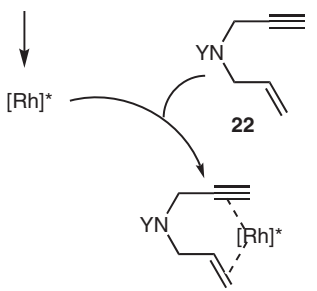

$M=[R h]^{*} H$

$R^{2}$<smiles>[R]/C=C\CCC</smiles>

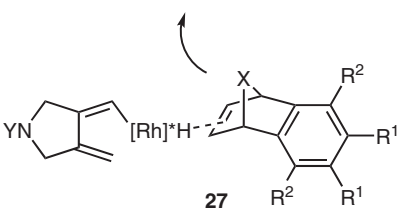

24

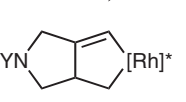

25<smiles>[R]c1c([R])c([R])c2c(c1[R])C1C=CC2C1[X]</smiles><smiles>C=C1CN(I)CC1=C[In-]</smiles>

26

Scheme 7 Synthesis of 3,4-dimethylene-pyrrolidines through a Rh-catalyzed domino reaction

the asymmetric synthesis of spiroindolines $\mathbf{4 2} .{ }^{19}$ The latter were obtained in good to excellent yields (50-99\%), diastereoselectivities ( 50 to $>90 \%$ de) as well as enantioselectivities (70-97\% ee) via the ring-opening reaction of the corresponding meso-aziridines $\mathbf{4 3}$ with C2-substituted 2-isocyanoethylindoles $\mathbf{4 4}$ followed by intramolecular cyclization (Scheme 11).

\subsection{Six-Membered Rings}

In 2016, chiral tricyclic indolines $\mathbf{4 8}$ were synthesized by Reisman et al. through the one-step reaction of amidoacrylate 45 with indoles 46 promoted by a combination of $\mathrm{ZrCl}_{4}$ with chiral BINOL-derived ligand $\mathbf{4 7 .}{ }^{20}$ As illustrated in
Scheme 12, the process occurred with high enantioselectivities $(81-91 \%$ ee), moderate diastereoselectivities (50-66\% de) and good yields (66-93\%). The domino reaction evolved through successive Michael addition, protonation and azaPrins reaction.

Asymmetric domino reactions can also be promoted by chiral green copper catalysts. ${ }^{21}$ For example, in 2016, chiral 5,6-dihydrocanthin-4-ones $\mathbf{5 1}$ were prepared in good yields (57-92\%) and enantioselectivities (68 to $>99 \%$ ee) from a domino reaction promoted by a chiral copper catalyst derived from CuI and chiral proline derivative $\mathbf{5 0}$. $^{22}$ The reaction occurred between terminal alkynes $\mathbf{3 0}$ and 1 -formyl$9 H$ - $\beta$-carbolines 49 (Scheme 13). The mechanism involved 
<smiles>[R]c1ccc2c(c1)cc([2H])n2C(=O)c1cc([2H])c([2H])c([R])c1Br</smiles>
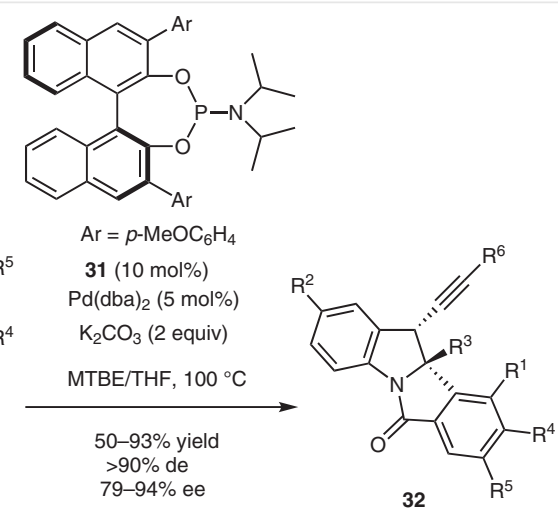

$\mathrm{R}^{1}=\mathrm{H}, \mathrm{Me}$

$\mathrm{R}^{2}=\mathrm{H}, i-\mathrm{Pr}, \mathrm{Me}, \mathrm{Cl}, \mathrm{F}$

$\mathrm{R}^{3}=\mathrm{Me}, \mathrm{Ph}, \mathrm{p}-\mathrm{F}_{3} \mathrm{CC}_{6} \mathrm{H}_{4}$, 2-furyl, Et, $\mathrm{CO}_{2} \mathrm{Me}$

$\mathrm{R}^{4}=\mathrm{H}, \mathrm{OMe}$

$\mathrm{R}^{5}=\mathrm{H}, \mathrm{OMe}, \mathrm{Me}, \mathrm{F}$

$\mathrm{R}^{6}=\mathrm{Ph}, p-\mathrm{MeOC}_{6} \mathrm{H}_{4}, p$-Tol, $p$ - $\mathrm{FC}_{6} \mathrm{H}_{4}, p-\mathrm{ClC}_{6} \mathrm{H}_{4}, p$-(Pent) $\mathrm{C}_{6} \mathrm{H}_{4}, p-\mathrm{PhC}_{6} \mathrm{H}_{4}$, $p$ - $\mathrm{F}_{3} \mathrm{CC}_{6} \mathrm{H}_{4}, p$-(PentO) $\mathrm{C}_{6} \mathrm{H}_{4}, p-(t-\mathrm{Bu}) \mathrm{C}_{6} \mathrm{H}_{4}, p-\left(\mathrm{MeO}_{2} \mathrm{C}\right) \mathrm{C}_{6} \mathrm{H}_{4}, p-\mathrm{NCC}_{6} \mathrm{H}_{4}$ $p-\mathrm{NCCH}_{2} \mathrm{C}_{6} \mathrm{H}_{4}, p-\left(\mathrm{F}_{3} \mathrm{CO}\right) \mathrm{C}_{6} \mathrm{H}_{4}, p-(\mathrm{OHC}) \mathrm{C}_{6} \mathrm{H}_{4}, m-\mathrm{Tol}, m-\mathrm{MeOC}_{6} \mathrm{H}_{4}$,

$m-\mathrm{FC}_{6} \mathrm{H}_{4}, m-\mathrm{ClC}_{6} \mathrm{H}_{4}, o-\mathrm{Tol}, o-\mathrm{F}_{3} \mathrm{CC}_{6} \mathrm{H}_{4}, o-\mathrm{ClC}_{6} \mathrm{H}_{4}, o-\mathrm{FC}_{6} \mathrm{H}_{4}$,

2-Naph, 2-thienyl, 1-thienyl, 3-pyridyl, 2-ferrocenyl, $\mathrm{CH}(\mathrm{OEt})_{2}, t-\mathrm{Bu}, \mathrm{PhthNCH}_{2}$ $\mathrm{Cl}\left(\mathrm{CH}_{2}\right)_{4}, \mathrm{HO}\left(\mathrm{CH}_{2}\right)_{4}, \mathrm{HO}\left(\mathrm{CH}_{2}\right)_{2}$, TMS, $(\mathrm{Me}) \mathrm{C}=\mathrm{CH}_{2}$

Scheme 8 Synthesis of 2,3-disubstituted indolines through a Pd-catalyzed domino reaction

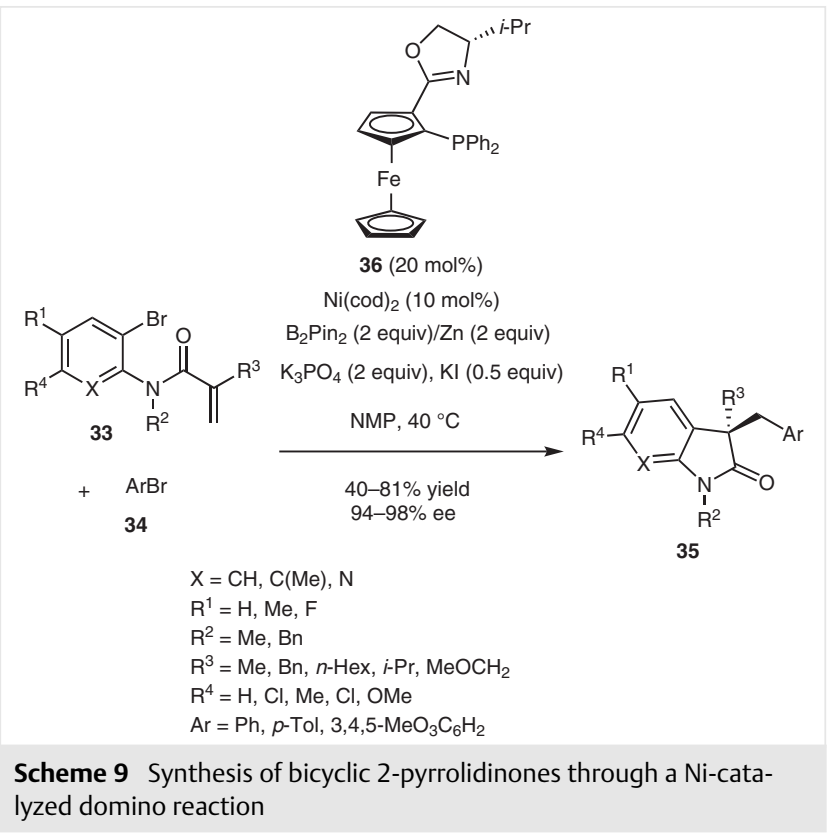

the formation of iminium species $\mathbf{5 2}$ from aldehyde $\mathbf{4 9}$ and amine catalyst $\mathbf{5 0}$. Then, iminium ion $\mathbf{5 2}$ reacted with copper-coordinated alkyne $\mathbf{5 3}$ to give intermediate $\mathbf{5 4}$, which subsequently underwent an intramolecular aza-Michael addition to afford the final product.

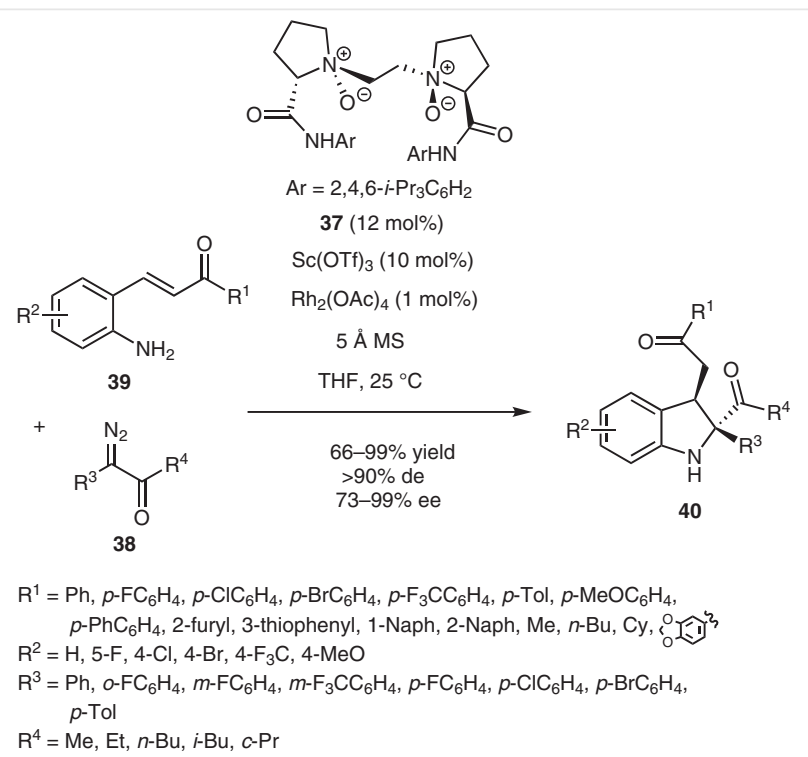

Scheme 10 Synthesis of 2,2,3-trisubstituted indolines through a Rhand Sc-catalyzed domino reaction

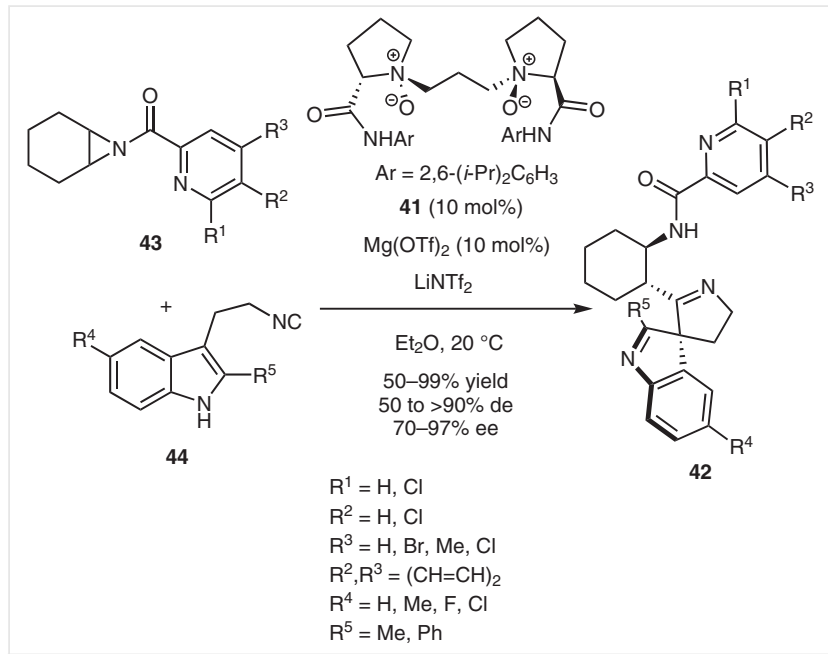

Scheme 11 Synthesis of spiroindolines through a Mg-catalyzed domino reaction

Another green metal, magnesium, ${ }^{23}$ has been used by Lin et al. in a recent synthesis of chiral spirooxindole tetrahydroquinolines $\mathbf{5 7}$ based on an intramolecular domino reaction of oxindoles $\mathbf{5 5} .^{24}$ The process occurred through sequential 1,5-hydride transfer and cyclization reactions carried out in the presence of a combination of $\mathrm{MgCl}_{2}$ and chiral phosphoric acid $\mathbf{5 6}$ (Scheme 14). The products were formed in high yields (80-95\%) and diastereoselectivities ( 80 to $>90 \%$ de) combined with good enantioselectivities (50-97\% ee). 

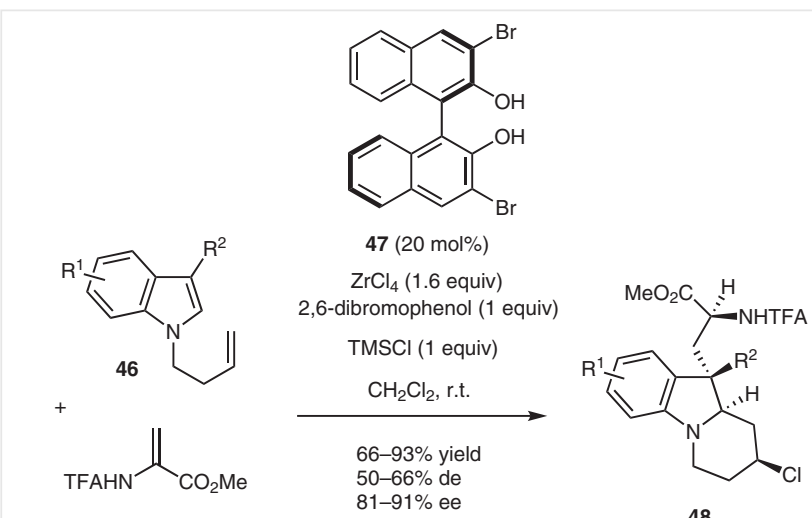

45

$\mathrm{R}^{1}=\mathrm{H}$, 1-Me, 2-Me, 3-Me, 4-Me, 2-OMe, 2-Br $\mathrm{R}^{2}=\mathrm{Me}$, allyl, Bn

\section{mechanism:}<smiles>[R]c1cn(CCC=C)c2c[Y17]ccc12</smiles>

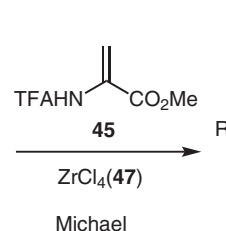

46

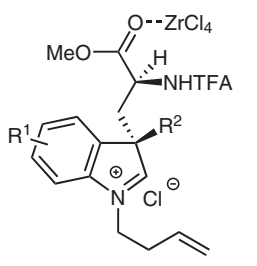

aza-Prins cyclization
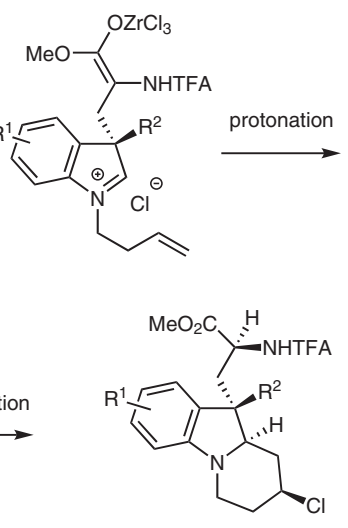

48

Scheme 12 Synthesis of tricyclic chiral indolines through a $\mathrm{Zr}$-catalyzed domino reaction

Another chiral magnesium catalyst derived from $\mathrm{MgSO}_{4}$ and a chiral phosphoric acid ligand $\mathbf{6 0}$ was applied by Schneider and Hodik in 2018 to develop a synthesis of chiral spirocyclic dihydroquinolones $\mathbf{6 1}$ through the reaction of ortho-quinone methide imines $\mathbf{5 8}$ with cyclic $\beta$-oxo esters 59 (Scheme 15). ${ }^{25}$ This one-step process evolved through successive addition and lactamization reactions, affording spirocyclic dihydroquinolones $\mathbf{6 1}$ with good yields (39-98\%) and both moderate to excellent diastereo- (50 to $>90 \%$ de) and enantioselectivities (66-98\% ee).

\section{Formation of One Ring Containing One Oxygen/Sulfur Atom}

\subsection{Five-Membered Rings}

In 2017, Ge et al. disclosed a synthesis of chiral tetrahydrofurans 63 on the basis of a domino reaction of oxygentethered 1,6-enynes $\mathbf{6 2}$ with pinacolborane (Scheme 16). ${ }^{11}$ The process employed a combination of $\mathrm{Co}(\mathrm{acac})_{2}$ with chiral biphosphine ligand $\mathbf{1 6}$ as the catalyst system, allowing

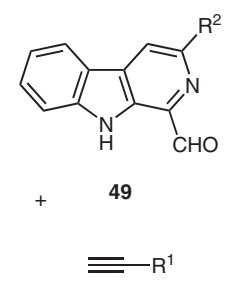

30
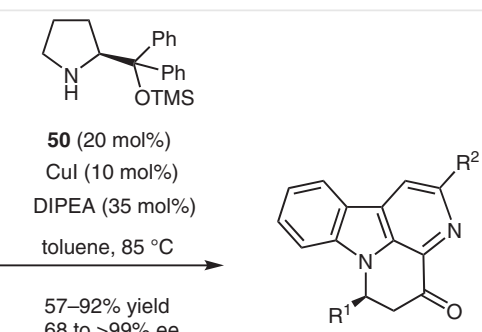

51
$\mathrm{R}^{1}=\mathrm{Ph}, p-t-\mathrm{BuC}_{6} \mathrm{H}_{4}, p-\mathrm{FC}_{6} \mathrm{H}_{4}, p-\mathrm{ClC}_{6} \mathrm{H}_{4}, p-\mathrm{BrC}_{6} \mathrm{H}_{4}, p-\mathrm{Tol}, p-\mathrm{MeOC}_{6} \mathrm{H}_{4}$, $m$ - $\mathrm{FC}_{6} \mathrm{H}_{4}, m$-Tol, 2-pyridyl, 2-cyclohexenyl, $n$ - $\mathrm{Bu}, \mathrm{CO}_{2} \mathrm{Me}$, 2-thienyl, $p$ - $n$ - $\mathrm{BuC}_{6} \mathrm{H}_{4}, p-\mathrm{PhOC}_{6} \mathrm{H}_{4}, p-\mathrm{MeO}$ (2-Naph), 3,4- $\mathrm{Cl}_{2} \mathrm{C}_{6} \mathrm{H}_{3}$ $\mathrm{R}^{2}=\mathrm{CO}_{2} \mathrm{Me}, \mathrm{H}$

proposed mechanism:<smiles>[R]c1cc2c([nH]c3ccccc32)c(C=O)n1</smiles>

49

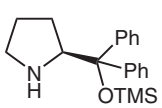

50

Cul

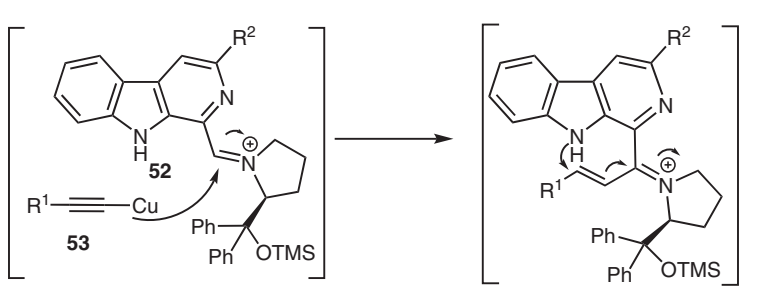

54

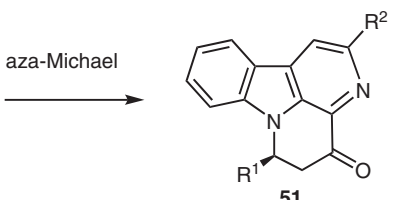

Scheme 13 Synthesis of 5,6-dihydrocanthin-4-ones through a Cu-catalyzed domino reaction

products 63 to be obtained with homogeneous excellent enantioselectivities (92-99\% ee) and good yields (47-87\%). The process evolved through an anti-Markovnikov hydroboration followed by a cyclization.

On the other hand, chiral alkyl boronate esters 65, instead of chiral vinyl-substituted boronate esters $\mathbf{6 3}$ (Scheme $16)$, were generated from the reaction of more sterically hindered oxygen-tethered 1,6-enynes 64 with pinacolborane in the presence of the same catalyst system. ${ }^{11}$ Indeed, in this case, a Markovnikov hydroboration occurred, delivering, after subsequent cyclization, tetrahydrofurans $\mathbf{6 5}$ in high yields (69-91\%) and enantioselectivities (86-92\% ee) (Scheme 17).

In 2018, Fan and co-workers reported the synthesis of chiral tetrahydrofuran $\mathbf{6 8}$ through a domino reaction between oxygen-tethered 1,6-enyne $\mathbf{6 6}$ and azabenzonorbornadiene $\mathbf{6 7}$ performed in the presence of a combination of 


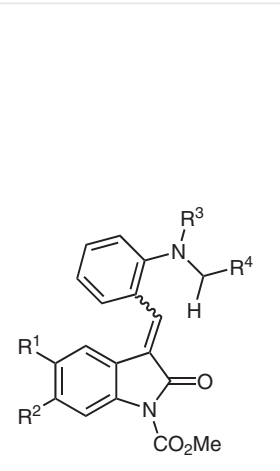

55

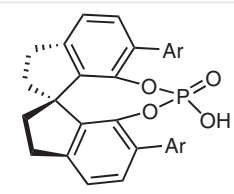

$\operatorname{Ar}=9$-phenanthryl

56 (10 mol\%)

$\mathrm{MgCl}_{2}(2.5 \mathrm{~mol} \%)$

$4 \AA ̊ \mathrm{MS}$

toluene, $80{ }^{\circ} \mathrm{C}$
$80-95 \%$ yield
80 to $>90 \%$ de
$50-97 \%$.

$50-97 \%$ ee

$\mathrm{R}^{1}=\mathrm{H}, \mathrm{NO}_{2}, \mathrm{~F}, \mathrm{Br}, \mathrm{Me}$

$\mathrm{R}^{2}=\mathrm{H}, \mathrm{Cl}$

$\mathrm{R}^{3}, \mathrm{R}^{4}=\left(\mathrm{CH}_{2}\right)_{3},\left(\mathrm{CH}_{2}\right)_{4}$

$\mathrm{R}^{3}=\mathrm{Bn}, \mathrm{R}^{4}=\mathrm{Ph}$

Scheme 14 Synthesis of spirooxindole tetrahydroquinolines through a Mg-catalyzed domino reaction

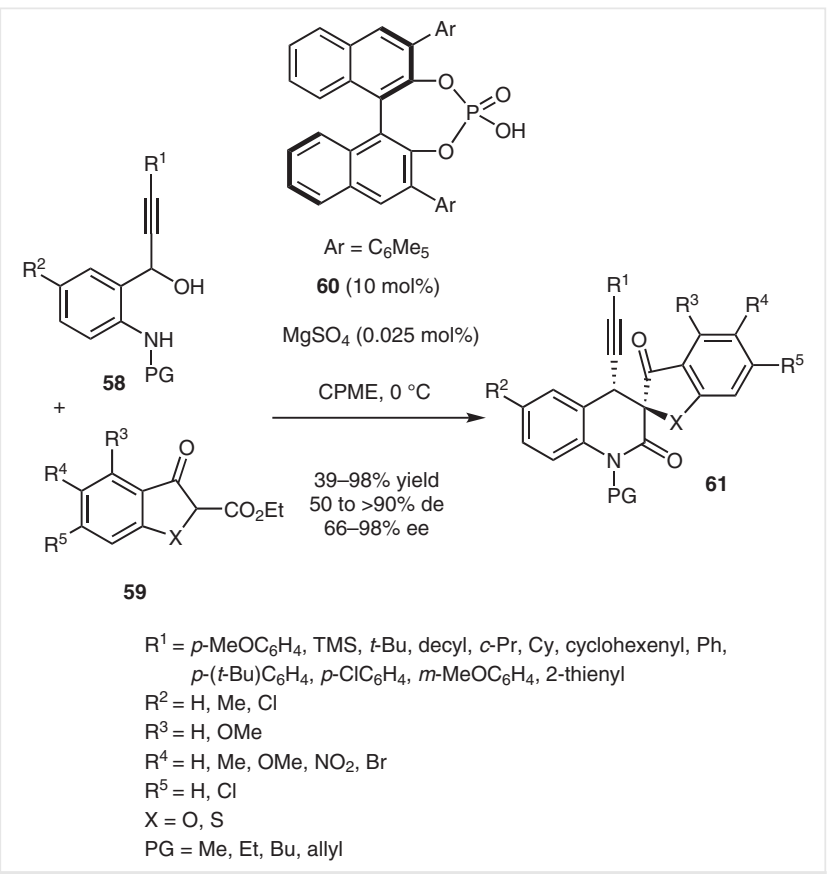

Scheme 15 Synthesis of spirocyclic dihydroquinolones through a Mgcatalyzed domino reaction

$\left[\mathrm{Rh}(\operatorname{cod})_{2}\right] \mathrm{BF}_{4}$ and chiral diphosphine ligand $(R)$-An-SDP. ${ }^{12}$ The enantiopure product ( $98 \%$ ee) was obtained in $38 \%$ yield through cyclization followed by an addition reaction (Scheme 18).

A synthesis of chiral bicyclic furans 72 was disclosed in 2018 by Marinetti and Betzer through a silver-catalyzed domino reaction of 2-(1-alkynyl)-2-cyclohexenone 69 with 5-substituted indoles 70 (Scheme 19). ${ }^{26}$ The process was catalyzed by preformed chiral silver phosphate $\mathbf{7 1}$ and evolved through successive cycloisomerization and addi-

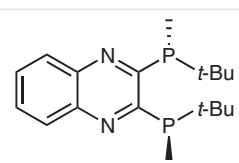

$16(4 \mathrm{~mol} \%)$
$\overbrace{62}^{O}$

$\mathrm{Co}(\mathrm{acac})_{2}(3 \mathrm{~mol} \%)$

toluene, r.t.

+ HBPin

$47-87 \%$ yield

92-99\% ee

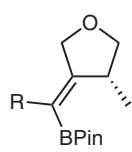

63

$$
\begin{aligned}
\mathrm{R}= & \mathrm{Ph}, p-\mathrm{F}_{3} \mathrm{CC}_{6} \mathrm{H}_{4}, p-\mathrm{MeOC}_{6} \mathrm{H}_{4}, p-\mathrm{Tol}, p-t-\mathrm{BuC}_{6} \mathrm{H}_{4}, p-\mathrm{TMSC}_{6} \mathrm{H}_{4}, \\
& p-\mathrm{FC}_{6} \mathrm{H}_{4}, p-\mathrm{ClC}_{6} \mathrm{H}_{4}, p-\mathrm{BrC}_{6} \mathrm{H}_{4}, m-\mathrm{Tol}_{1}, p-\mathrm{AcC}_{6} \mathrm{H}_{4}, p-\mathrm{OHCC}_{6} \mathrm{H}_{4}, \\
& p-\mathrm{MeO}_{2} \mathrm{CC}_{6} \mathrm{H}_{4}, p-\mathrm{NCC}_{6} \mathrm{H}_{4}, p-\mathrm{TBSOC}_{6} \mathrm{H}_{4}, 2 \text {-thienyl, BnO }\left(\mathrm{CH}_{2}\right)_{3}, \\
& \left(2-\mathrm{Naph}(\mathrm{O}) \mathrm{CO}\left(\mathrm{CH}_{2}\right)_{3}, 3\right. \text {-pyridyl, }
\end{aligned}
$$

Scheme 16 Synthesis of tetrahydrofurans through a Co-catalyzed domino reaction

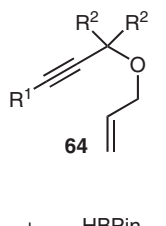

$+\quad$ HBPin
$16(4 \mathrm{~mol} \%)$

$\mathrm{Co}(\mathrm{acac})_{2}(3 \mathrm{~mol} \%)$

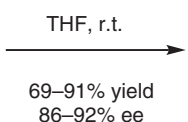

$86-92 \%$ ee

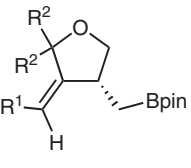

$\mathrm{R}^{1}=o$-Tol, 2-Naph, Ph, $p$-Tol, $p$ - $-\mathrm{BuC}_{6} \mathrm{H}_{4}, p-\mathrm{F}_{3} \mathrm{CC}_{6} \mathrm{H}_{4}, m$-Tol $\mathrm{R}^{2}=\mathrm{H}, \mathrm{Me}, \mathrm{Ph}$

$\mathrm{R}^{2}, \mathrm{R}^{2}=\left(\mathrm{CH}_{2}\right)_{3},\left(\mathrm{CH}_{2}\right)_{4},\left(\mathrm{CH}_{2}\right)_{5},\left(\mathrm{CH}_{2}\right)_{6},\left(\mathrm{CH}_{2}\right)_{7}$,

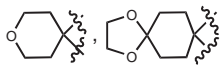

Scheme 17 Synthesis of other tetrahydrofurans through a Co-catalyzed domino reaction

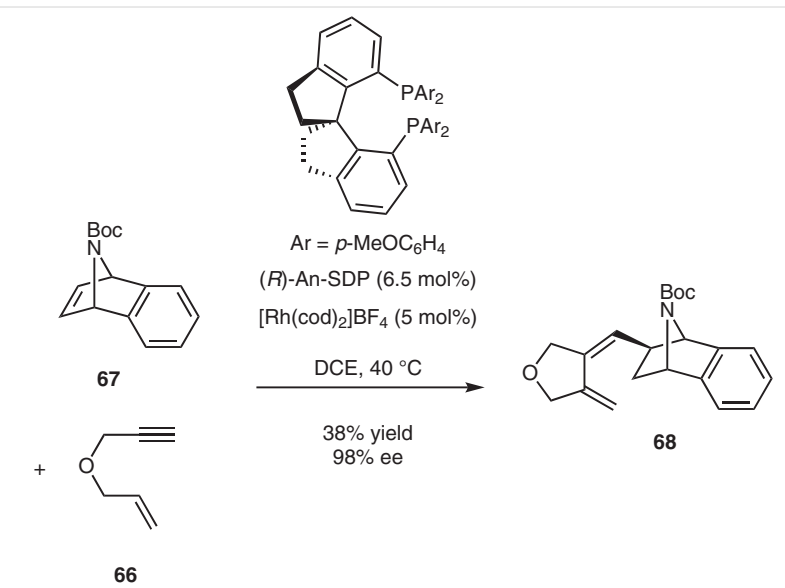

Scheme 18 Synthesis of a tetrahydrofuran through a Rh-catalyzed domino reaction 


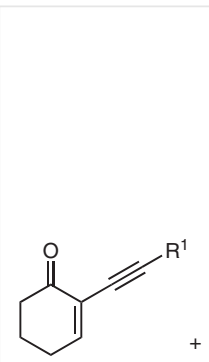

69

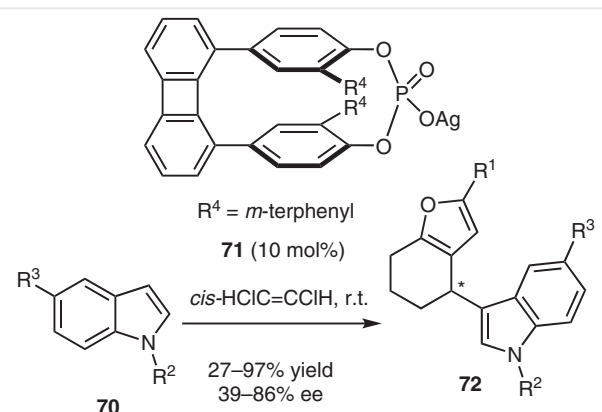

$\mathrm{R}^{1}=\mathrm{Ph}, p-\mathrm{MeOC}_{6} \mathrm{H}_{4}, \mathrm{Bn}$
$\mathrm{R}^{2}=\mathrm{He}$

$\mathrm{R}^{3}=\mathrm{H}, \mathrm{Me}, \mathrm{F}, \mathrm{OMe}$

Scheme 19 Synthesis of bicyclic furans through an Ag-catalyzed domino reaction

tion reactions to deliver the final bicyclic furans $\mathbf{7 2}$ in variable yields (27-97\%) and moderate to high enantioselectivities (39-86\% ee).

Chiral 3-substituted isobenzofuranones 76 were generated by Gros et al. through a magnesium-catalyzed domino reaction occurring between ethyl 2-iodobenzoate (73) and aldehydes $74 .^{27}(\mathrm{~S})$-BIPHEN-BuMgLi was used as the cata-

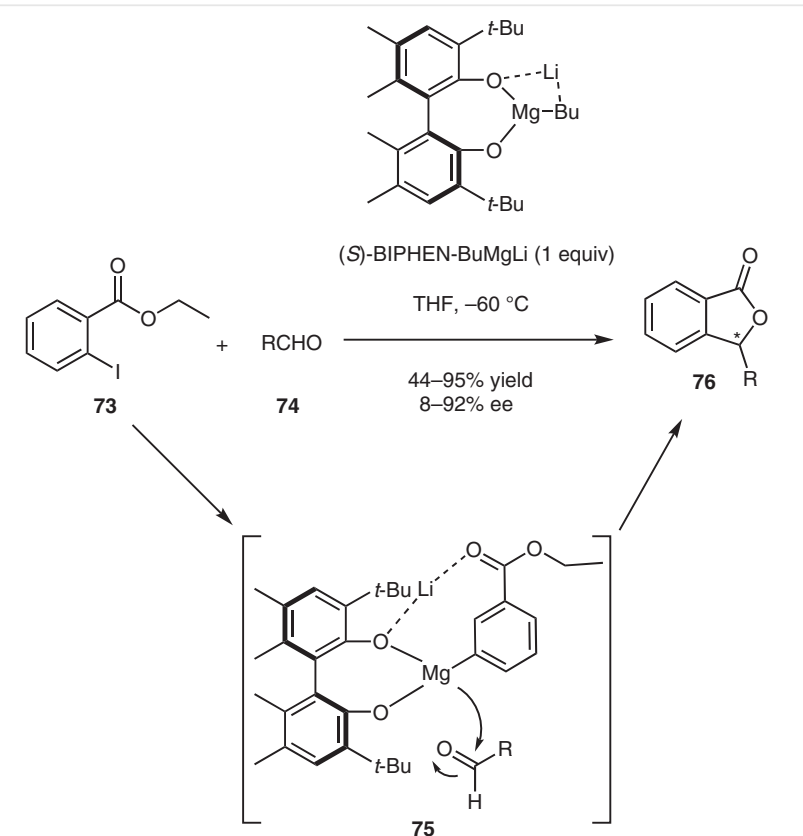

$\mathrm{R}=p-\mathrm{MeOC}_{6} \mathrm{H}_{4}, m-\mathrm{MeOC}_{6} \mathrm{H}_{4}, o-\mathrm{MeOC}_{6} \mathrm{H}_{4}, 2,4,6-(\mathrm{MeO})_{3} \mathrm{C}_{6} \mathrm{H}_{2}, 3,4,5-(\mathrm{MeO})_{3} \mathrm{C}_{6} \mathrm{H}_{2}$, $p$ - $\mathrm{ClC}_{6} \mathrm{H}_{4}, m-\mathrm{ClC}_{6} \mathrm{H}_{4}, p-\mathrm{F}_{3} \mathrm{CC}_{6} \mathrm{H}_{4}, p-\mathrm{FC}_{6} \mathrm{H}_{4}, p-(t-\mathrm{Bu}) \mathrm{C}_{6} \mathrm{H}_{4}$, 2-Naph, 2-thienyl, 2-pyridyl, $n$-Pent, piperidinyl, -

Scheme 20 Synthesis of 3-substituted isobenzofuranones through a $\mathrm{Mg}$-catalyzed domino reaction lyst, which formed intermediate $\mathbf{7 5}$ on reaction with ethyl 2-iodobenzoate (73). Addition of the latter to aldehyde $\mathbf{7 4}$ followed by intramolecular cyclization then led to final product 76 in variable enantioselectivities (8-92\% ee) and good to excellent yields (44-95\%) (Scheme 20).

Chiral tetrahydrothiophenes $\mathbf{8 0}$ were produced by Punniyamurthy et al. through an iron-catalyzed domino reaction of aromatic $\alpha, \beta$-unsaturated ketones 1 and 77 with 1,4dithiane-2,5-diol (78). ${ }^{28} \mathrm{~A}$ combination of $\mathrm{FeCl}_{3}$ with novel reusable chiral dendrimer ligand 79 was used as the catalyst system, which triggered successive sulfa-Michael addition and aldol condensation to give chiral tetrahydrothiophenes $\mathbf{8 0}$ as single diastereomers (>99\% de) in low to high yields (21-84\%) and enantioselectivities (16-70\% ee) (Scheme 21).

In 2019, Wang et al. reported the synthesis of chiral 3,3'dihydrofuran spirooxindoles $\mathbf{8 1}$ on the basis of an enantioselective zinc-catalyzed three-component reaction of isatins 82, $\alpha$-hydroxy ketones 83 and malononitrile $84 . .^{29}$ The process involved a bimetallic catalyst generated in situ from $\mathrm{ZnEt}_{2}$ and chiral triol ligand 85. It evolved through a domino Knoevenagel/Michael/cyclization reaction, affording highly functionalized spirooxindoles $\mathbf{8 1}$ in uniformly high yields (82-99\%), variable diastereoselectivities (4-98\% de) and high enantioselectivities in most cases (6 to >99\% ee) (Scheme 22).

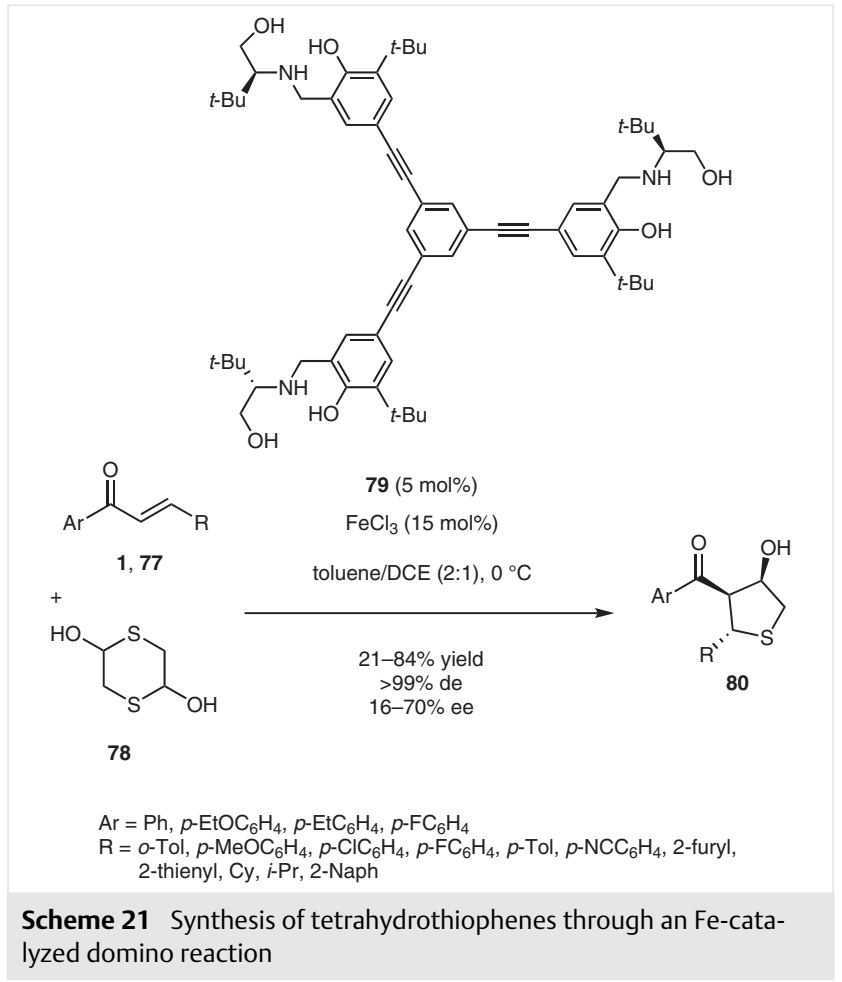




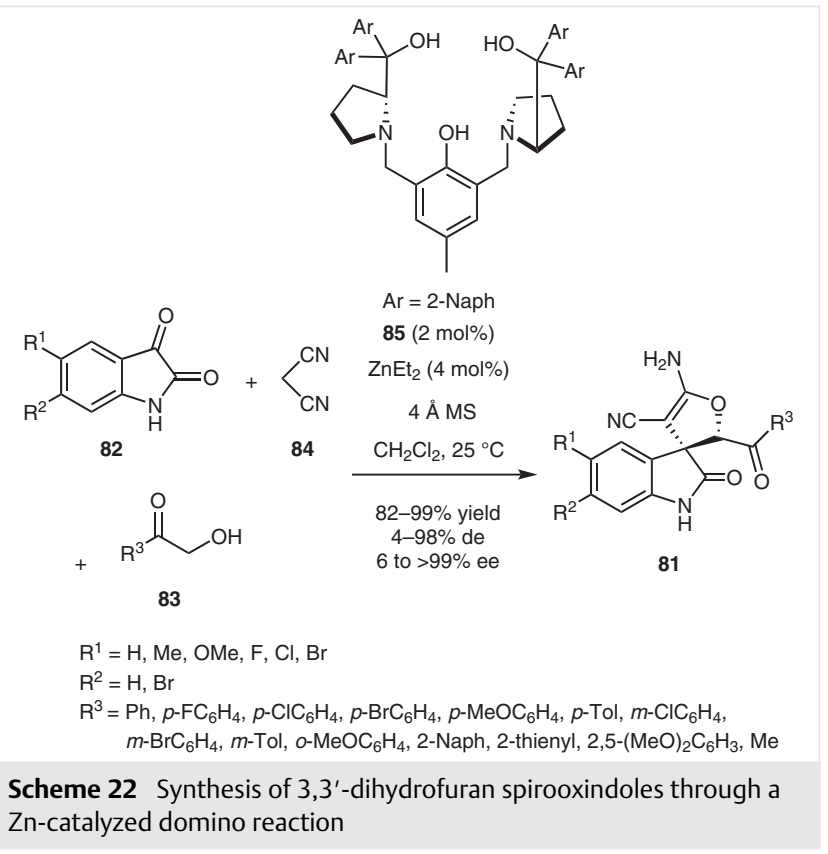

\subsection{Six-Membered Rings}

In 2016, densely functionalized chiral chromans 89 were synthesized by Schneider et al. by using $\left[\mathrm{Rh}_{2}(\mathrm{OAc})_{4}\right]$ and chiral phosphoric acid $\mathbf{8 8}$ as the catalyst system. ${ }^{30} \mathrm{As}$ shown in Scheme 23, the reaction of ortho-hydroxy benzhydryl alcohols $\mathbf{8 6}$ with diazoesters 87 evolved through the Michael addition of rhodium carbene $\mathbf{9 1}$ to intermediate ortho-quinone methides $\mathbf{9 0}$. This was followed by a hemiketalization reaction of intermediate $\mathbf{9 2}$ leading to chiral chromans 89 as single diastereomers in good yields (5587\%) and high enantioselectivities (78-96\% ee).

Tietze et al. disclosed the synthesis of another chiral chroman, constituting a key intermediate in a total synthesis of (-)-siccanin, by using a chiral palladium catalyst derived from Pd(TFA $)_{2}$ and the $(R, R)$-Bn-BOXAX ligand. ${ }^{31}$ Alkenyl phenol 93 reacted through Wacker oxidation, carbonylation and then methoxylation to afford chiral chroman $\mathbf{9 4}$ in $93 \%$ ee and $71 \%$ yield (Scheme 24 ).

In 2018, Quintard and Rodriguez reported the synthesis of chiral bicyclic $\delta$-lactones 98 through domino reactions of cyclic $\beta$-keto esters 95 with allylic alcohols 96 , by employing a combination of achiral iron tricarbonyl complex 97, $\mathrm{Cu}(\mathrm{acac})_{2}$ and chiral proline derivative $\mathbf{5 0}^{32}$ The process evolved through successive oxidation, Michael addition, reduction and lactonization to give bicyclic $\delta$-lactones 98 in high enantioselectivities (90-93\% ee) combined with low to moderate yields (21-51\%) (Scheme 25).<smiles>[12H]c1ccc(O)c(C(O)c2cc(Br)c(Br)cc2Br)c1</smiles>

86<smiles>N=C(C(=O)O)C(=O)O</smiles>

87

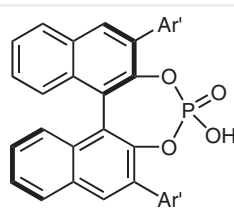

$A r^{\prime}=3,5-\left(\mathrm{CF}_{3}\right)_{2} \mathrm{C}_{6} \mathrm{H}_{3}$ $88(5 \mathrm{~mol} \%)$ $\left[\mathrm{Rh}_{2}(\mathrm{OAc})_{4}\right](2 \mathrm{~mol} \%)$ $\mathrm{CHCl}_{3}$, r.t. $55-87 \%$ yield $78-96 \%$ ee

$\mathrm{R}^{1}=\mathrm{H}, \mathrm{OMe}, \mathrm{t}-\mathrm{Bu}$ $\mathrm{R}^{2}=\mathrm{H}, \mathrm{Et}, \mathrm{Me}$ $\mathrm{R}^{3}=\mathrm{H}, \mathrm{Me}, \mathrm{Ph}, t-\mathrm{Bu}, \mathrm{Cl}, \mathrm{F}$ $\mathrm{R}^{4}=\mathrm{H}, \mathrm{OMe}$ $\mathrm{R}^{5}=\mathrm{Et}, \mathrm{Me}$

$\mathrm{Ar}=\mathrm{Ph}, p$-Tol, $m$-Tol, $o$-Tol, $p-\mathrm{O}_{2} \mathrm{NC}_{6} \mathrm{H}_{4}, p-\mathrm{MeOC}_{6} \mathrm{H}_{4}, p-\mathrm{PhC}_{6} \mathrm{H}_{4}$, $p-\mathrm{FC}_{6} \mathrm{H}_{4}, p-\mathrm{ClC}_{6} \mathrm{H}_{4}, p-\mathrm{BrC}_{6} \mathrm{H}_{4}$, 2-Naph

proposed mechanism:<smiles>[2H]c1ccc([2H])c(C(O)c2cc([2H])ccc2O)c1</smiles>

86<smiles>[R]C1=CC(C(c2cc([2H])c([2H])cc2[2H])C(O)(O)C(C)(O)C(C)=O)C(O)C=C1</smiles>

92

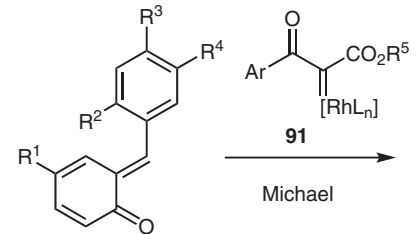<smiles>[2H]c1ccc([C@H]2c3cc([123I])ccc3O[C@@H](O)C2(O)O)c([2H])c1</smiles>

Scheme 23 Synthesis of chromans through a Rh-catalyzed domino reaction

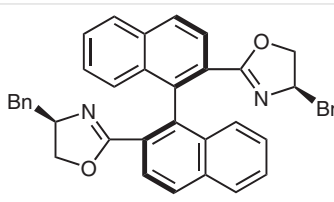

(R, R)-Bn-BOXAX (20 mol\%) $\mathrm{Pd}(\mathrm{TFA})_{2}(5 \mathrm{~mol} \%)$

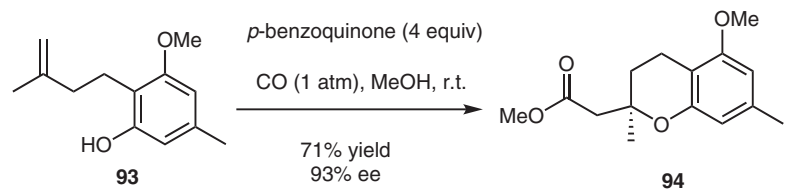

Scheme 24 Synthesis of a chroman through a Pd-catalyzed domino reaction 


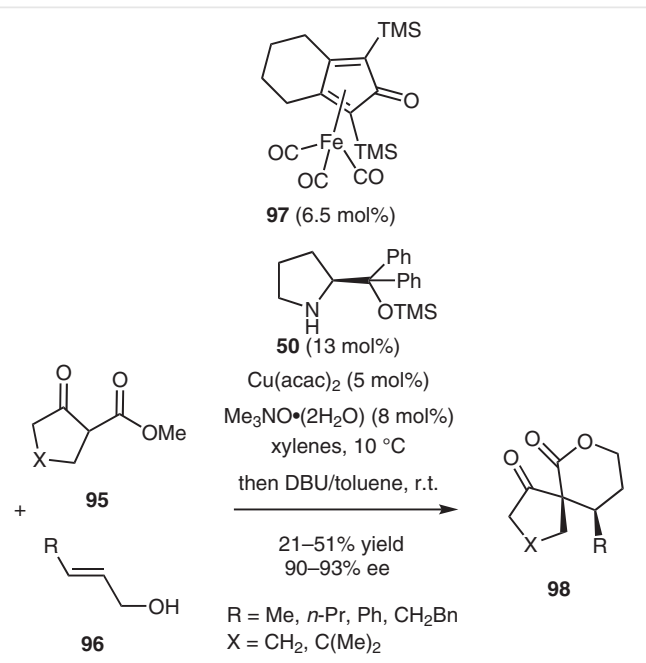

Scheme 25 Synthesis of bicyclic $\delta$-lactones through a multicatalyzed domino reaction

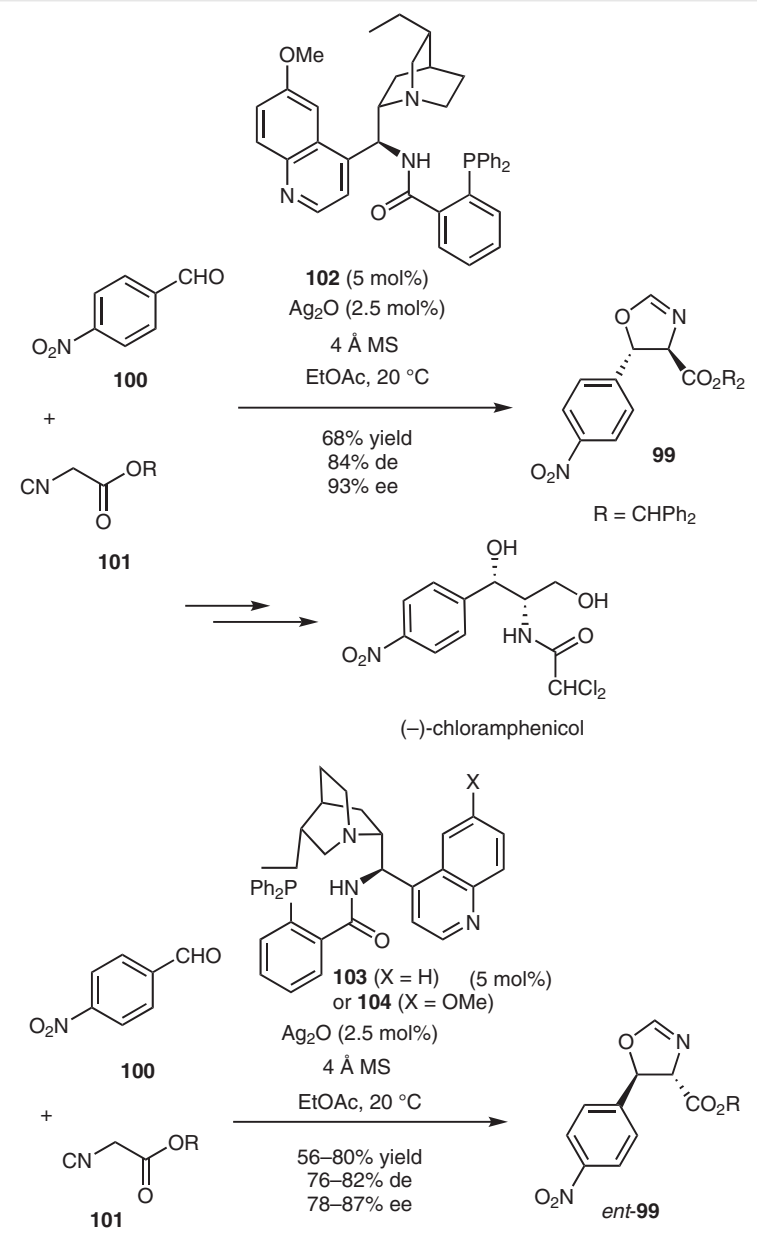

$\mathrm{R}=t-\mathrm{Bu}, \mathrm{Me}, \mathrm{Bn}, p-\mathrm{MeOC}_{6} \mathrm{H}_{4} \mathrm{CH}_{2}, 3,5-\left(\mathrm{F}_{3} \mathrm{C}_{2} \mathrm{C}_{6} \mathrm{H}_{3} \mathrm{CH}_{2}\right.$

Scheme 26 Synthesis of oxazolines through Ag-catalyzed domino reactions

\section{Formation of One Ring Containing Several Heterocyclic Atoms}

In 2016, Dixon et al. employed a combination of $\mathrm{Ag}_{2} \mathrm{O}$ and chiral cinchona alkaloid $\mathbf{1 0 2}$ to develop a novel total synthesis of the antibiotic (-)-chloramphenicol. ${ }^{33}$ Actually, the latter was obtained from trans-oxazoline 99, itself prepared from a domino reaction occurring between $p$-nitrobenzaldehyde (100) and isocyanoacetate $\mathbf{1 0 1}$ with $93 \%$ ee, $84 \%$ de and $68 \%$ yield. The process evolved through sequential aldol and cyclization reactions. It was found that other alkyl isocyanoacetates $\mathbf{1 0 1}$ were also compatible by using related chiral cinchona alkaloid ligands 103 and 104, thus leading to chiral oxazolines ent-99 in good yields (56-80\%), diastereo- (76-82\% de) and enantioselectivities (78-87\% ee) (Scheme 26).

In the same year, Feng et al. employed a catalyst system composed of $\mathrm{Mg}(\mathrm{OTf})_{2}$ and chiral $N, N^{\prime}$-dioxide ligand 105 in the synthesis of chiral 2-alkyl-5-aminooxazoles 108. ${ }^{34}$ The process involved the Michael addition of $\alpha$-isocyanoacetamides 107 to alkylidene malonates $\mathbf{1 0 6}$ followed by an intramolecular cyclization reaction to provide chiral 2-alkyl5 -aminooxazoles 108 in variable yields (28-99\%) and good enantioselectivities (72-96\% ee) (Scheme 27).

In 2019, the same authors employed related chiral $N, N^{\prime}-$ dioxide ligand 41 combined with $\mathrm{Mg}(\mathrm{OTf})_{2}$ to promote the asymmetric synthesis of other 2-alkyl-5-aminooxazoles 109. ${ }^{19}$ The latter were obtained in good to excellent yields (40-99\%) and enantioselectivities (50-95\% ee) from the ring-opening reaction of the corresponding meso-aziridines $\mathbf{4 3}$ with $\alpha$-isocyanoacetamides 107 followed by intramolecular cyclization (Scheme 28).

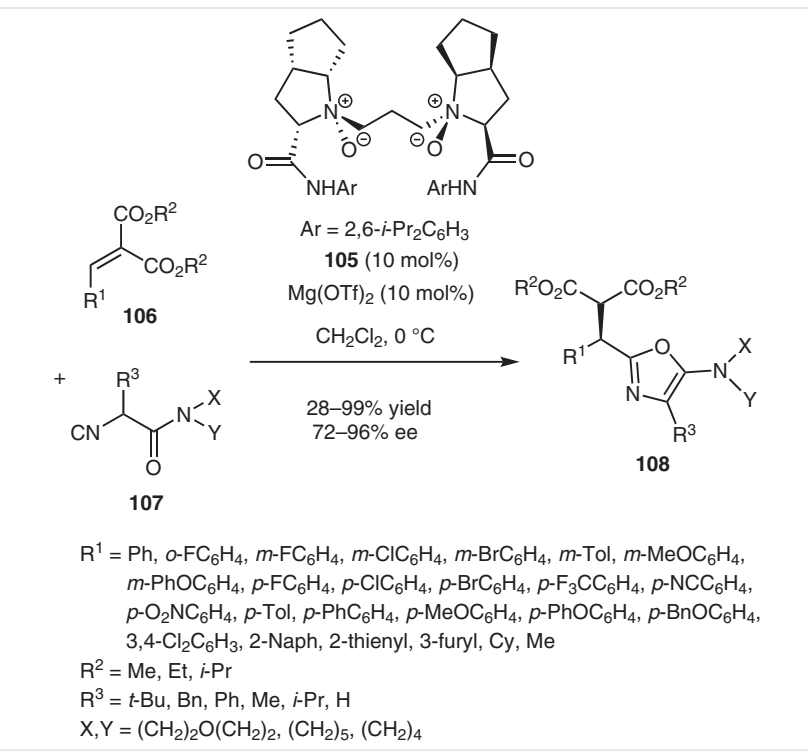

Scheme 27 Synthesis of 2-alkyl-5-aminooxazoles through a Mg-catalyzed domino reaction 


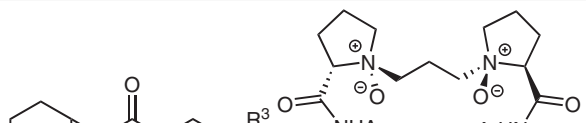

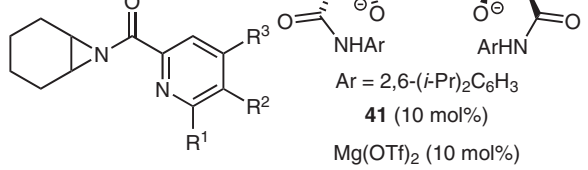

$$
\begin{aligned}
& 43 \\
& \mathrm{Na}_{2} \mathrm{CO}_{3} \\
& \prod_{O}^{N_{-}^{\prime}} \overbrace{-Y}^{X} \\
& \mathrm{Et}_{2} \mathrm{O}, 20^{\circ} \mathrm{C} \\
& 40-99 \% \text { yield } \\
& 50-90 \% \text { ee } \\
& 107 \mathrm{R}^{1}=\mathrm{H}, \mathrm{Cl} \\
& \mathrm{R}^{2}=\mathrm{H}, \mathrm{Cl} \\
& \mathrm{R}^{1}, \mathrm{R}^{2}=(\mathrm{CH}=\mathrm{CH})_{2} \\
& \mathrm{R}^{3}=\mathrm{H}, \mathrm{Me}, \mathrm{Cl}, \mathrm{Br} \\
& \mathrm{R}^{4}=\mathrm{Bn}, t \text {-Bu, } i \text { - } \mathrm{Pr}, i-\mathrm{Bu}, \mathrm{Ph} \\
& \mathrm{X}, \mathrm{Y}=\left(\mathrm{CH}_{2}\right)_{2} \mathrm{O}\left(\mathrm{CH}_{2}\right)_{2},\left(\mathrm{CH}_{2}\right)_{5},\left(\mathrm{CH}_{2}\right)_{4}
\end{aligned}
$$

Scheme 28 Synthesis of other 2-alkyl-5-aminooxazoles through a Mgcatalyzed domino reaction

A chiral scandium catalyst derived from $\mathrm{Sc}(\mathrm{OTf})_{3}$ and chiral diphosphine oxide ligand $\mathbf{1 1 1}$ was applied by Shi et al. to promote the synthesis of chiral aryl 5-bromo-1,3-oxazinan-2-ones 112 (Scheme 29). ${ }^{35}$ The reaction occurred between $(E)$-cinnamyl tosylcarbamates $\mathbf{1 1 0}$ and 1,3-dibromo-5,5-dimethylhydantoin (DBDMH) through successive bromination and amination reactions, delivering the domino products in excellent enantioselectivities (87-99\% ee) and good to excellent yields (65-96\%).

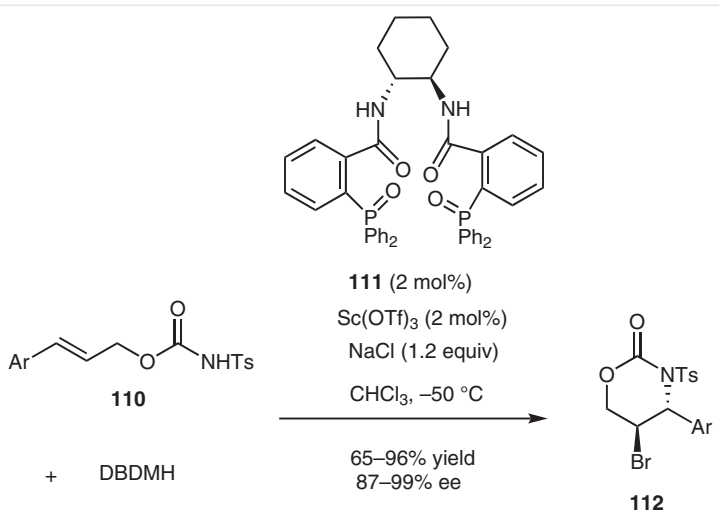

$\mathrm{Ar}=\mathrm{Ph}, p-\mathrm{MeOC}_{6} \mathrm{H}_{4}, m-\mathrm{MeOC}_{6} \mathrm{H}_{4}, o-\mathrm{MeOC}_{6} \mathrm{H}_{4}, p-\mathrm{BrC}_{6} \mathrm{H}_{4}, m-\mathrm{BrC}_{6} \mathrm{H}_{4}$, $p$ - $\mathrm{ClC}_{6} \mathrm{H}_{4}, m-\mathrm{FC}_{6} \mathrm{H}_{4}, p-\mathrm{FC}_{6} \mathrm{H}_{4}, 2,4,6-\mathrm{F}_{3} \mathrm{C}_{6} \mathrm{H}_{2}, o$-Tol, $p$-Tol,

3,5- $\mathrm{Me}_{2} \mathrm{C}_{6} \mathrm{H}_{3}, 2,4,6-\mathrm{Me}_{3} \mathrm{C}_{6} \mathrm{H}_{2}$, 1-Naph, 2-Naph, 2-thienyl

Scheme 29 Synthesis of aryl 5-bromo-1,3-oxazinan-2-ones through a Sc-catalyzed domino reaction

A novel route to chiral 3,4-dihydro-2H-1,2,4-benzothiadiazine-1,1-dioxides 115 was disclosed in 2016 by Zhou et al. using a catalyst system based on $\mathrm{Sc}(\mathrm{OTf})_{3}$ and chiral Pybox (pyridine-bisoxazoline) ligand $114 .^{36}$ The process involved imine formation using aldehydes 74 and 2-aminobenzenesulfonamide (113), followed by an intramolecular amination reaction to provide products $\mathbf{1 1 5}$ in good yields (60-88\%) and enantioselectivities (36-93\% ee) (Scheme $30)$.

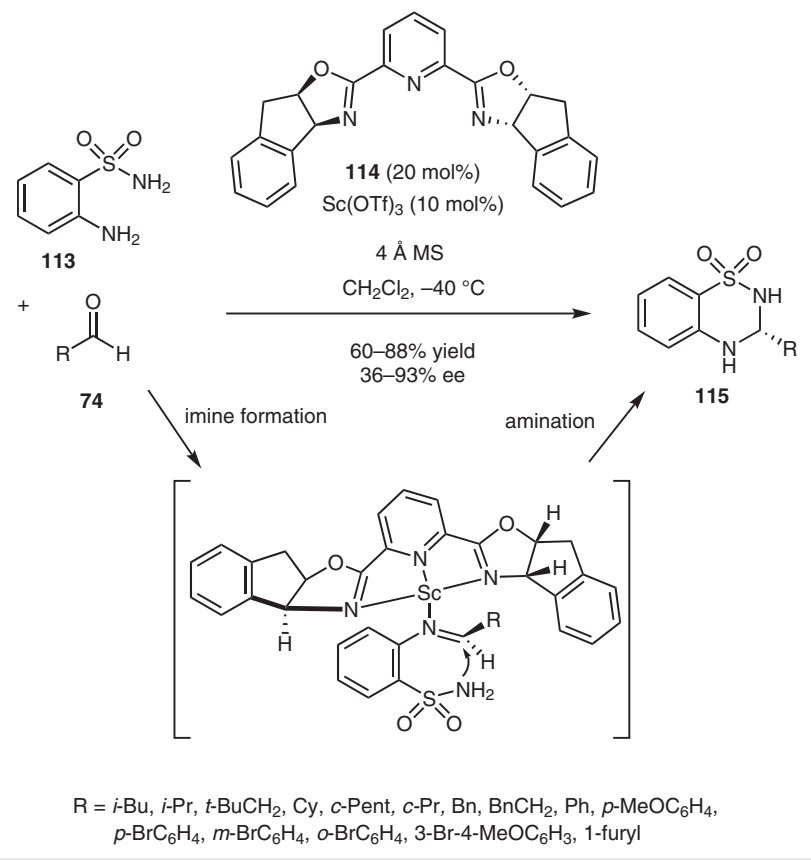

Scheme 30 Synthesis of 3,4-dihydro-2H-1,2,4-benzothiadiazine-1,1dioxides through a Sc-catalyzed domino reaction

In 2016, Liu and Feng described the first asymmetric synthesis of benzimidazoles based on a metal-catalyzed domino process. ${ }^{37}$ The catalyst system was generated from $\mathrm{ScCl}_{3} \cdot\left(\mathrm{H}_{2} \mathrm{O}\right)_{6}$ and chiral $N, N^{\prime}$-dioxide ligand 121 (Scheme 31). The reaction occurred between cyclopropanes 116 and diamines 117, which firstly underwent a ring-opening addition reaction to give $\mathbf{1 1 8}$. The latter intermediate was then submitted to an intramolecular cyclization to provide 119 and a subsequent retro-Mannich reaction afforded the final products 120 in high enantioselectivities (80-97\% ee) and good yields (56-99\%).

\section{Formation of One Carbon Ring}

\subsection{Five-Membered Rings}

In 2016, Enders et al. reported the synthesis of chiral spiropyrazolones $\mathbf{1 2 5}$ on the basis of a relay multicatalysis with $\mathrm{Ag}_{2} \mathrm{O}$ and chiral squaramide 124 as the organocatalyst. $^{38}$ The products were formed in variable yields (2799\%) from 5-pyrazolones 122 and alkyne-tethered nitroalkenes $\mathbf{1 2 3}$ through consecutive organocatalyzed Michael addition and Ag-catalyzed Conia-ene reaction. As presented in Scheme 32, high diastereoselectivities (78 to 
$>90 \%$ de) combined with good enantioselectivities (42-99\% ee) were obtained.

In the same year, Ratovelomanana-Vidal, Michelet and Vitale described a novel diastereo- and enantioselective for-

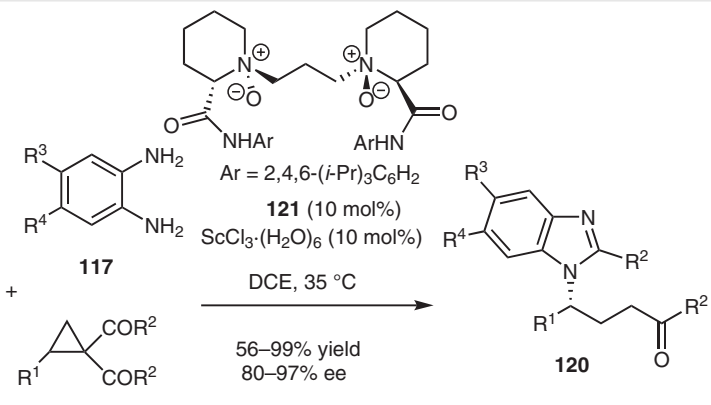

116

$\mathrm{R}^{1}=\mathrm{Ph}, p-\mathrm{MeOC}_{6} \mathrm{H}_{4}, p-\mathrm{Tol}, p-\mathrm{FC}_{6} \mathrm{H}_{4}, p-\mathrm{ClC}_{6} \mathrm{H}_{4}, p-\mathrm{BrC}_{6} \mathrm{H}_{4}, m-\mathrm{Tol}$, $m$ - $\mathrm{ClC}_{6} \mathrm{H}_{4}, o-\mathrm{Tol}, 3,4-\mathrm{Cl}_{2} \mathrm{C}_{6} \mathrm{H}_{3}, 1$-Naph, 2-Naph, vinyl, Me $\mathrm{R}^{2}=\mathrm{Ph}, p$ - Tol, $p$ - $\mathrm{FC}_{6} \mathrm{H}_{4}$

$\mathrm{R}^{3}=\mathrm{H}, \mathrm{Me}, \mathrm{OMe}, \mathrm{F}, \mathrm{Cl}, \mathrm{Br}, \mathrm{NO}_{2}$

$\mathrm{R}^{4}=\mathrm{H}, \mathrm{Me}, \mathrm{OMe}, \mathrm{F}, \mathrm{Cl}, \mathrm{Br}, \mathrm{NO}_{2}$

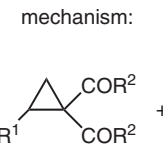

116

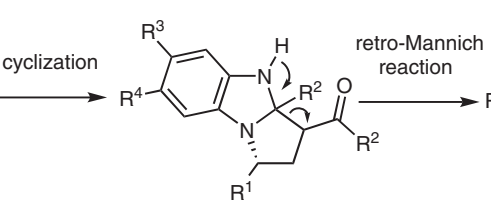

119

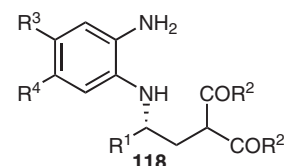

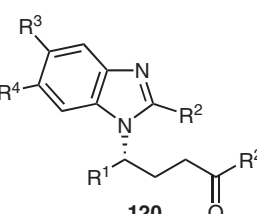

Scheme 31 Synthesis of benzimidazoles through a Sc-catalyzed domino reaction

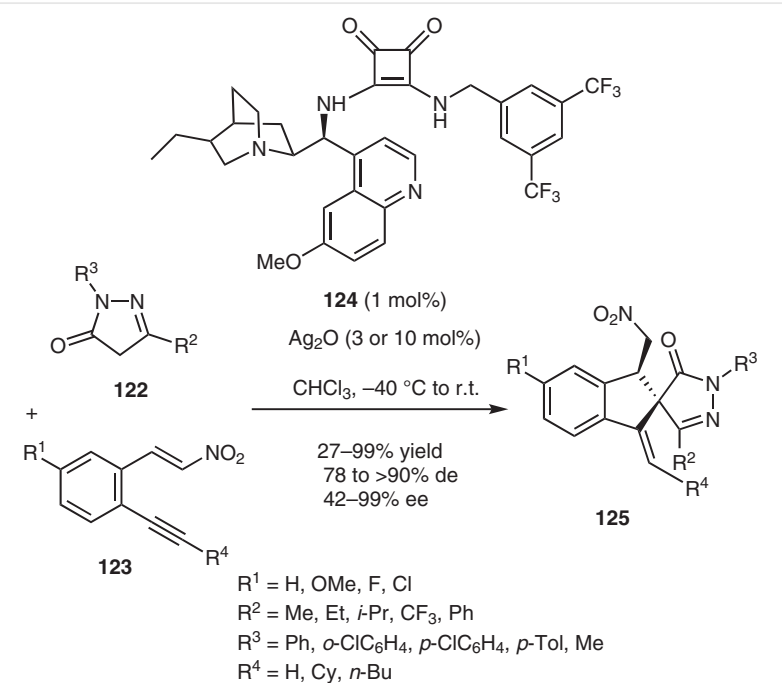

Scheme 32 Synthesis of spiropyrazolones through a multicatalyzed domino reaction mal [3+2] cycloaddition of vinyl cyclopropanes 126 with $\alpha, \beta$-unsaturated aldehydes 127 catalyzed by a combination of $\mathrm{Pd}_{2}(\mathrm{dba})_{3}\left(\mathrm{CHCl}_{3}\right)$, dppe as the ligand and proline-derived chiral amine $\mathbf{5 0}$ as the organocatalyst. ${ }^{39}$ The process evolved through a domino Michael/cyclization reaction, affording the corresponding enantiopure trisubstituted cyclopentanes 128 (>99\% ee) with good to high yields (54-88\%) and diastereoselectivities (72-80\% de) when starting from 1,1-dicyano-2-vinyl cyclopropane $\left[\mathrm{Z}=\mathrm{C}(\mathrm{CN})_{2}\right]$ (Scheme 33). The same synergistic catalytic system also promoted the reaction of other vinyl cyclopropanes, such as 1,3-indanedione-derived vinyl cyclopropane, Meldrum's acid derived vinyl cyclopropane and 1,3-dimethylbarbituric vinyl cyclopropane, which led to the corresponding enantiopure cyclopentanes 128 (>99\% ee) with low to excellent yields (29-98\%) and diastereoselectivities (24-82\% de), as shown in Scheme 33.

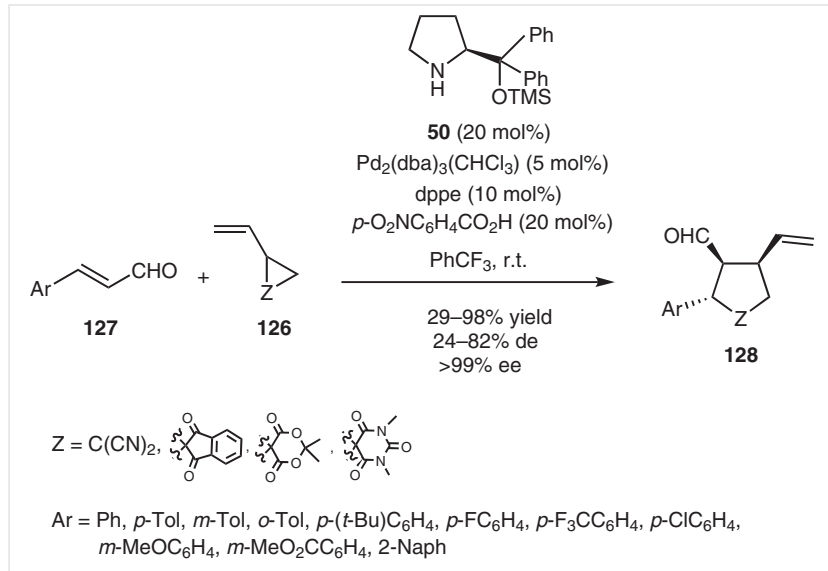

Scheme 33 Synthesis of trisubstituted cyclopentanes through a multicatalyzed domino reaction

This type of reaction was also investigated at the same time by Jørgensen et al. by using a related catalyst system, albeit employed at lower catalyst loadings. ${ }^{40}$ Indeed, performed in the presence of only $10 \mathrm{~mol} \%$ of organocatalyst 50 and $3 \mathrm{~mol} \%$ of $\mathrm{Pd}_{2}(\mathrm{dba})_{3}$, the domino Michael/cyclization reaction of $\alpha, \beta$-unsaturated aldehydes 127 with vinylcyclopropanes 129 led to the corresponding chiral pentasubstituted cyclopentanes 130 bearing up to four stereogenic centers, including one quaternary, with both uniformly high yields (80-97\%) and enantioselectivities (91 to >99\% ee), combined with moderate to high diastereoselectivities (42-82\% de) (Scheme 34). In addition to the vinyl cyclopropane 129 bearing two nitrile groups $(X=C N)$, vinyl cyclopropanes possessing a methyl or a benzyl ester were also compatible as were various aromatic $\alpha, \beta$-unsaturated aldehydes.

These reactions were also studied by Rios and Meazza almost at the same time. ${ }^{41}$ In this case, a combination of 20 mol\% of the same organocatalyst $\mathbf{5 0}$ with $5 \mathrm{~mol} \%$ of $\mathrm{Pd}_{2}(\mathrm{dba})_{3}$ was used. For example, the domino Michael/cy- 


$$
\text { (12) }
$$

Scheme 34 Synthesis of pentasubstituted cyclopentanes through a multicatalyzed domino reaction

clization reaction of spirocyclic vinyl cyclopropane $\mathbf{1 3 1}$ with a range of either aromatic or aliphatic $\alpha, \beta$-unsaturated aldehydes 127 afforded the corresponding chiral spirocyclic products 132 in high yields (76-96\%) and both moderate to high diastereo- (42-84\% de) and enantioselectivities (30$99 \%$ ee) (Scheme 35). The scope of the reaction could be extended to other vinyl cyclopropanes 133, which through reactions with aromatic $\alpha, \beta$-unsaturated aldehydes $\mathbf{1 2 7}$ led to the corresponding chiral cyclopentanes 134 in good to quantitative yields (50-99\%) combined with low diastereoselectivities (10-38\% de) and good to excellent enantioselectivities ( 76 to $>99 \%$ ee) (Scheme 35 ).

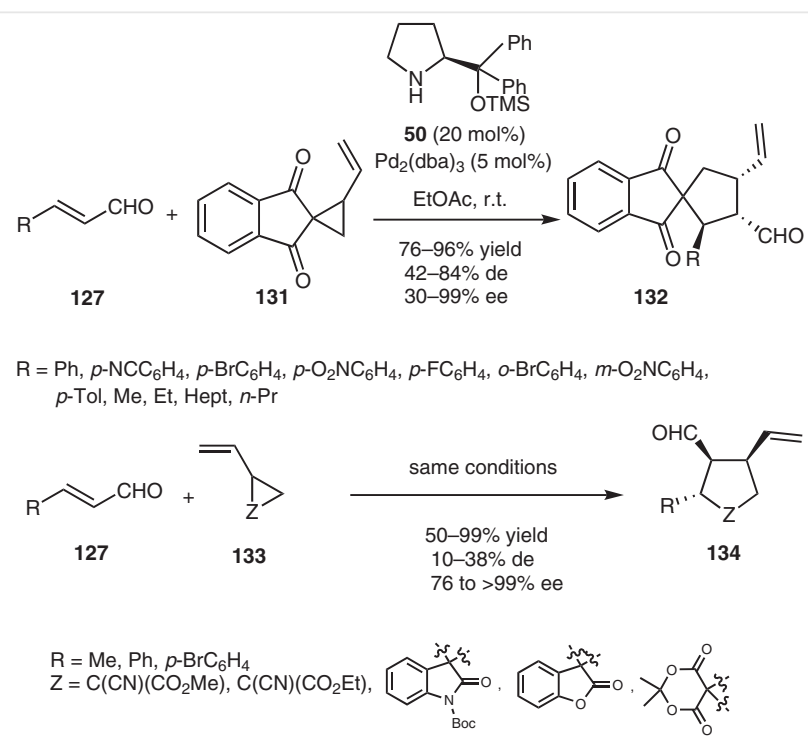

Scheme 35 Synthesis of spirocyclic cyclopentanes through multicatalyzed domino reactions

In 2017, Feng et al. employed a chiral yttrium catalyst prepared from $\mathrm{Y}(\mathrm{OTf})_{3}$ and chiral $N, N^{\prime}$-dioxide ligand 135 for the synthesis of chiral tetrasubstituted diquinanes. ${ }^{42}$ In this process, electron-deficient enynes 136 reacted with $\alpha, \beta$-unsaturated ester 137 through two sequential Michael

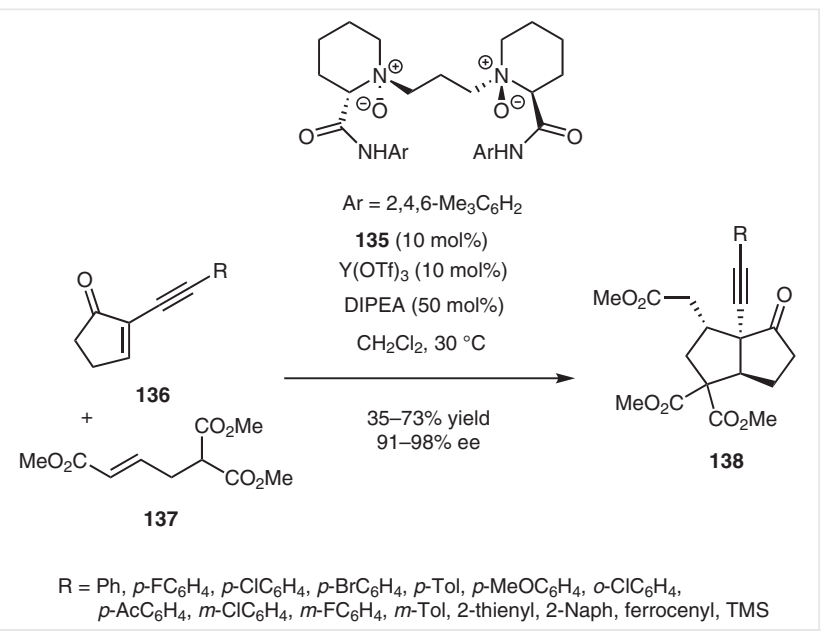

Scheme 36 Synthesis of diquinanes through a Y-catalyzed domino reaction

additions to afford almost enantiopure (91-98\% ee) diquinanes 138 in variable yields (35-73\%) (Scheme 36).

In the same year, Ge et al. described the synthesis of chiral cyclopentanes on the basis of a domino reaction promoted by a combination of $\mathrm{Co}(\mathrm{acac})_{2}$ and chiral biphosphine ligand 16. ${ }^{11}$ As depicted in Scheme 37, 1,6-enynes 139 reacted with pinacolborane through an antiMarkovnikov hydroboration followed by a cyclization to yield the corresponding enantiopure (99\% ee) vinyl-substituted boronate esters 140 in good yields (49-54\%).

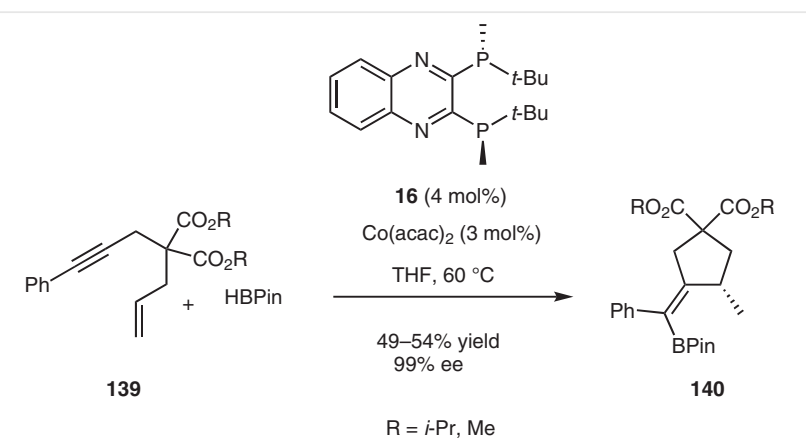

Scheme 37 Synthesis of functionalized cyclopentanes through a Cocatalyzed domino reaction

When the same reaction was performed in the presence of related chiral biphosphine ligand 19 instead of ligand $\mathbf{1 6}$, a Markovnikov hydroboration occurred (Scheme 38), which was followed by cyclization to give enantiopure (96-98\% ee) alkyl boronate esters 141 in good yields (50-63\%). ${ }^{11}$

In 2020, asymmetric nickel catalysis was applied by Ye and Peng to develop a novel synthesis of chiral indenes 142 bearing a quaternary stereocenter. ${ }^{43}$ Indeed, in the presence of $\mathrm{Ni}(\operatorname{cod})_{2}$ and $\alpha, \alpha, \alpha^{\prime}, \alpha^{\prime}$-tetraphenyl-2,2-dimethyl-1,3-di- 


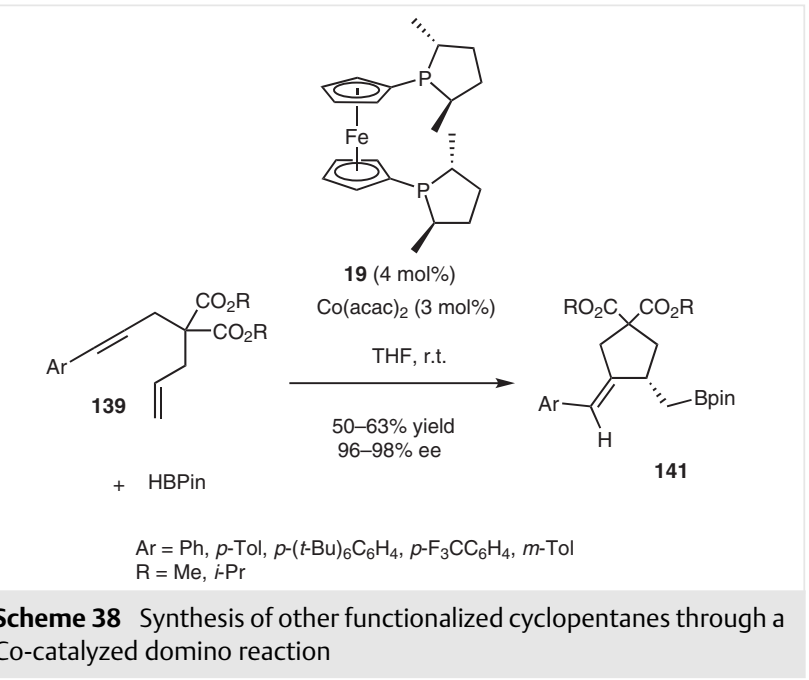

oxolane-4,5-dimethanol (TADDOL)-derived ligand 143, a range of aryl nitriles 144 reacted with internal alkynes 145 to give the corresponding indenes 142 in moderate to high yields (32-91\%) and good to high enantioselectivities (73$98 \%$ ee). The process required the use of an achiral phosphine and $\mathrm{Al}(i-\mathrm{Bu})_{3}$ as additives (Scheme 39).

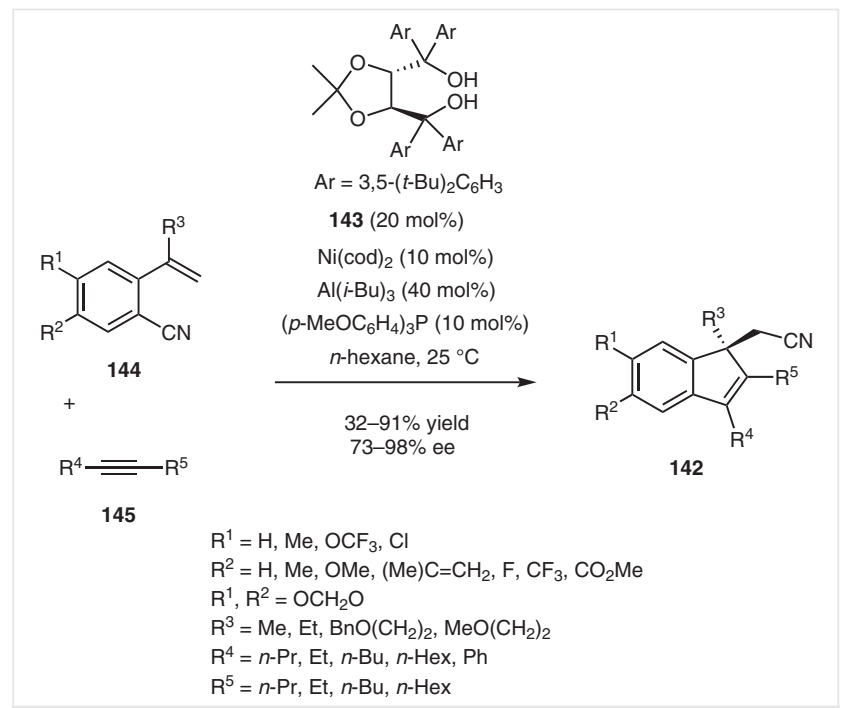

Scheme 39 Synthesis of indenes through a Ni-catalyzed domino reaction

\subsection{Six-Membered Rings}

In 2016, a catalyst system consisting of $\mathrm{ZrCl}_{4}$ and $(R)$-BINOL-derived ligand $\mathbf{4 7}$ was applied by Reisman and coworkers to elaborate an asymmetric synthesis of tricyclic indoles 148 (Scheme 40). ${ }^{20}$ These products were generated in good yields (70-99\%) from the reaction of indoles 146 with acrylate 147 through sequential Michael addition, protonation and an aza-Prins reaction. High enantioselectivities (85-93\% ee) combined with good diastereoselectivities (50-72\% de) were obtained.

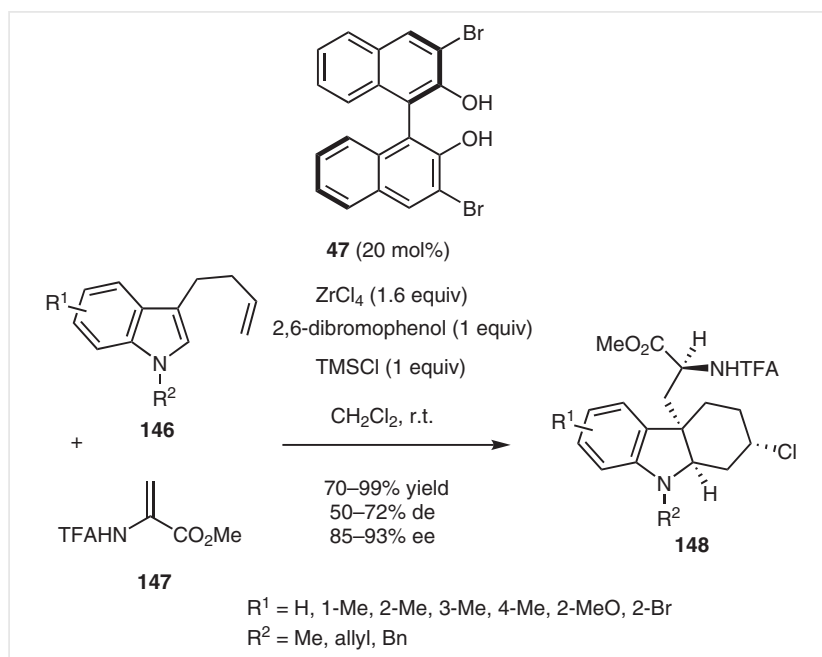

Scheme 40 Synthesis of tricyclic indoles through a Zr-catalyzed domino reaction

In 2018, chiral spiroindolinones were prepared by Feng and Lin from an enantioselective magnesium-catalyzed one-step reaction between $\alpha, \alpha$-dicyanoalkenes 149 and 3arylideneoxindoles 150. ${ }^{44}$ The reaction, evolving through Michael addition followed by cyclization, was performed in the presence of $\mathrm{Mg}(\mathrm{OTf})_{2}$ and chiral $N, N^{\prime}$-dioxide ligand 121 and led to chiral spiroindolinones $\mathbf{1 5 1}$ in high enantioselectivities ( 83 to $>99 \%$ ee), good yields (44-95\%) and variable diastereoselectivities (38-90\% de) (Scheme 41).

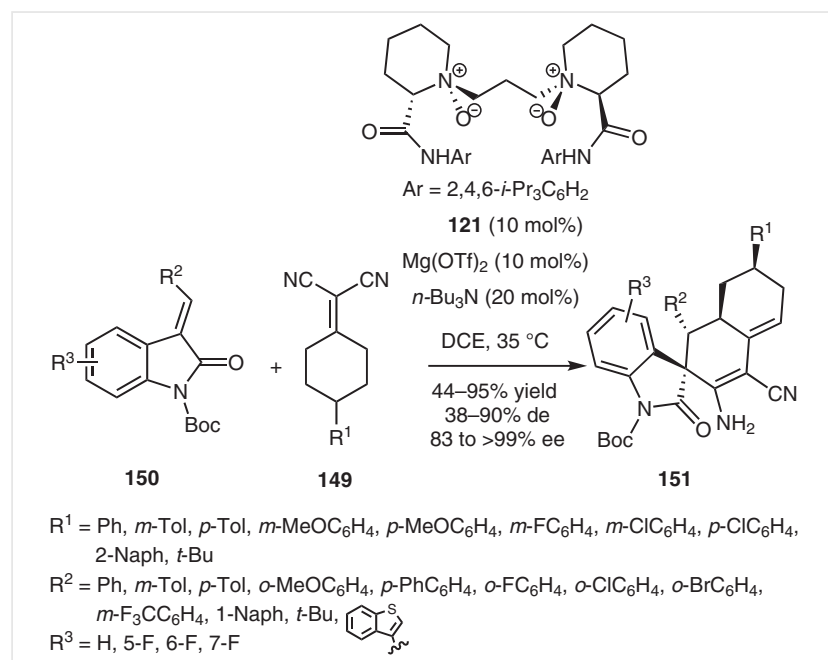

Scheme 41 Synthesis of spiroindolinones through a Mg-catalyzed domino reaction

In 2019, another chiral $N, N^{\prime}$-dioxide ligand 152 was combined with $\mathrm{Sc}(\mathrm{OTf})_{3}$ by Feng et al. to promote an asymmetric vinylogous Michael/aldol domino reaction of 
$\alpha$-arylidene pyrazolinones 153 with $\beta, \gamma$-unsaturated- $\alpha$-ketoester 154 (Scheme 42 ). ${ }^{45}$ The process was performed in aqueous media $\left(\mathrm{CH}_{2} \mathrm{Cl}_{2} / \mathrm{H}_{2} \mathrm{O}\right)$ and allowed a series of chiral spirocyclohexene pyrazolones $\mathbf{1 5 5}$ to be synthesized in good to high yields (60-99\%) and enantioselectivities (58$92 \%$ ee), combined with variable diastereoselectivities (18$72 \%$ de).

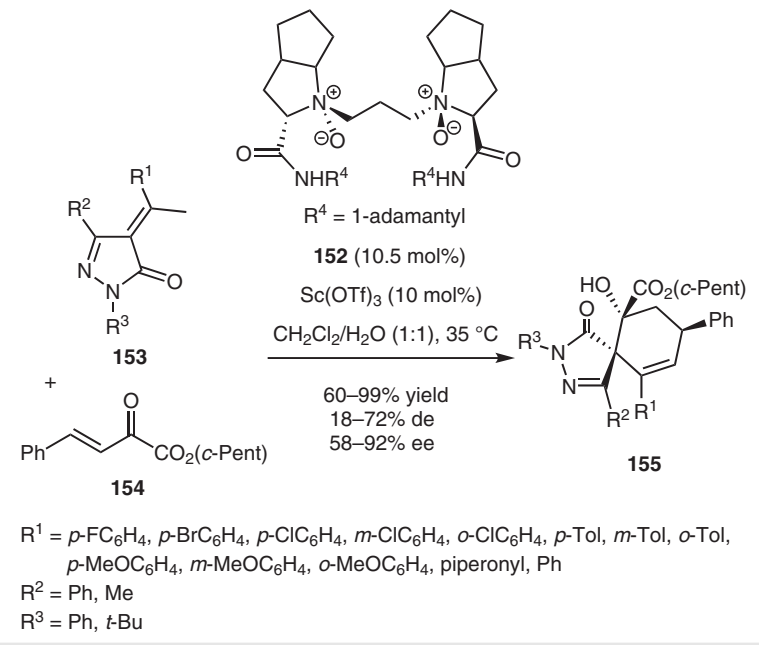

Scheme 42 Synthesis of spirocyclohexene pyrazolones through a Sccatalyzed domino reaction

\section{Formation of Two Rings}

In 2016, a combination of $\mathrm{AgNO}_{3} / \mathrm{Ag}_{2} \mathrm{O}$ and cinchona alkaloid ligand 156 was employed by Xie et al. in a novel asymmetric synthesis of cis-3a,8a-hexahydropyrrolo[2,3-

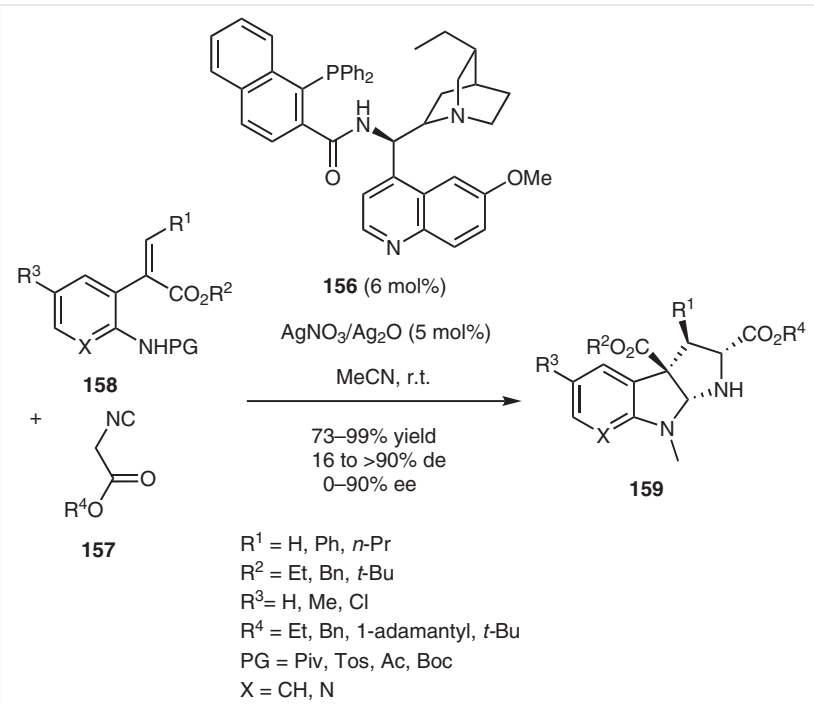

Scheme 43 Synthesis of cis-3a,8a-hexahydropyrrolo[2,3-b]indoles through an Ag-catalyzed domino reaction b]indoles 159. ${ }^{46}$ These multifunctionalized products arose from the reaction of isocyanoacetates 157 with acrylates 158 according to sequential Michael addition and cyclization reactions (Scheme 43). Good yields (73-99\%) and variable stereoselectivities ( 16 to $>90 \%$ de, $0-90 \%$ ee) were reported.

In the same context, these authors also disclosed the reaction of isocyanoacetates 161 with acrylates 160 to give, in the presence of $\mathrm{Ag}_{2} \mathrm{O}$ and related cinchona alkaloid ligand 102, the corresponding chiral tetrahydrobenzofuro[2,3b]pyrroles 162 as mixtures of two diastereomers (0.83-7.6 dr) in high yields (70-99\%) and variable enantioselectivities (26-87\% ee) (Scheme 44). ${ }^{47}$

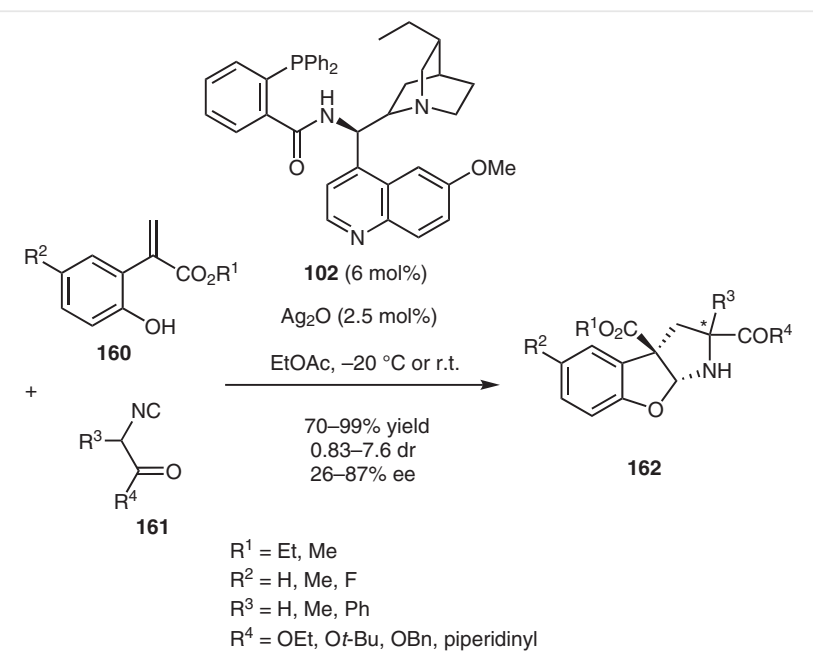

Scheme 44 Synthesis of tetrahydrobenzofuro[2,3-b]pyrroles through an Ag-catalyzed domino reaction

In 2018, chiral preformed magnesium catalyst 163 was used by Mori and Akiyama in an asymmetric synthesis of tricyclic piperidine $\mathbf{1 6 5}$ from cinnamylidene malonate 164 (Scheme 45). ${ }^{48}$ This substrate underwent an Ag-catalyzed [1,5]-hydride shift followed by a cyclization to provide piperidine 165 in $74 \%$ yield, $87 \%$ ee and $66 \%$ de.

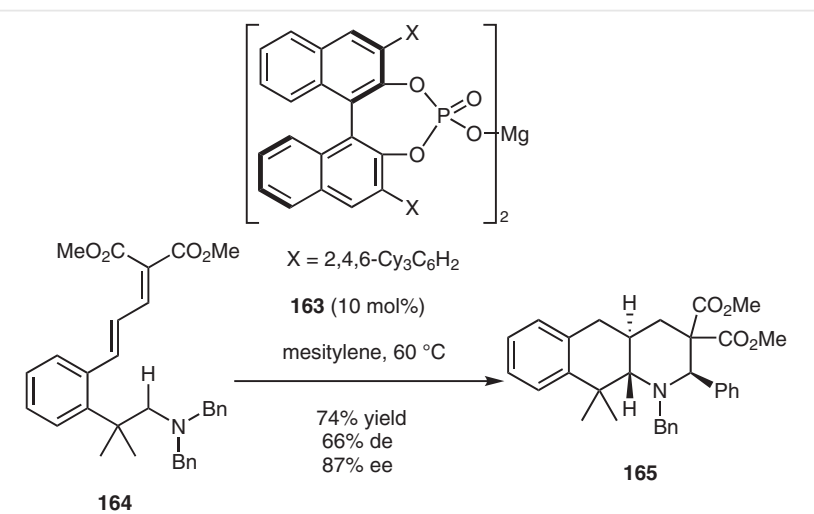

Scheme 45 Synthesis of a tricyclic piperidine through a Mg-catalyzed domino reaction 
In the same year, an asymmetric synthesis of spirocyclic lactams 169 was reported by Enders and co-workers using copper catalysis. ${ }^{49}$ Indeed, cyclohexadienones 167 reacted with nitrones 168 in the presence of $\mathrm{Cu}(\mathrm{OTf})_{2}$ and chiral bisoxazoline ligand $\mathbf{1 6 6}$ as the catalyst system to give domino products 169 in high enantioselectivities (82-97\% ee), good diastereoselectivities ( 72 to $>90 \%$ de) and moderate to excellent yields (55-94\%) through consecutive Kinugasa and Michael reactions (Scheme 46).

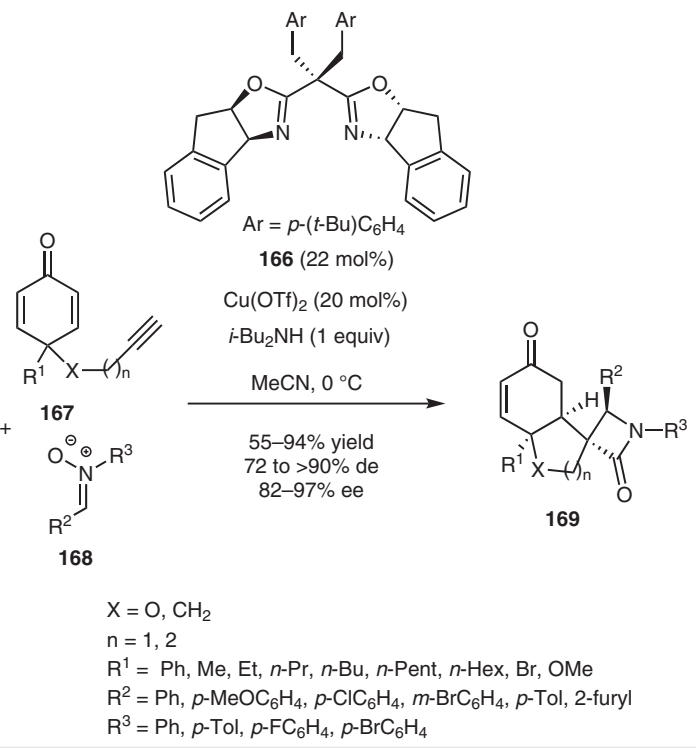

Scheme 46 Synthesis of spirocyclic lactams through a Cu-catalyzed domino reaction

Finally, asymmetric nickel catalysis was employed in 2019 by Kong et al. in a novel one-pot synthesis of chiral 2,3-fused cyclopentannulated indolines $\mathbf{1 7 0} .^{50}$ As illustrated in Scheme 47, these highly substituted products arose from the domino reaction occurring between internal alkynes 145 and acrylamides 171, which were performed in the presence of a combination of $\mathrm{NiCl}_{2}$ (DME) and chiral Pybox ligand $\mathbf{1 7 2}$ as the catalyst system and $\mathrm{Mn}$ as the reducing agent. These biologically interesting products were obtained as single regioisomers in variable yields (26-88\%) and uniformly excellent enantioselectivities (85-96\% ee).

In 2016, Feng and Liu reported an example of bimetallic asymmetric relay catalysis based on the use of a chiral nickel complex generated in situ from $\mathrm{Ni}\left(\mathrm{ClO}_{4}\right)_{2} \cdot 6 \mathrm{H}_{2} \mathrm{O}$ and chiral $N, N^{\prime}$-dioxide ligand 173 combined with an achiral gold catalyst, such as $\mathrm{AuCl}\left(\mathrm{PPh}_{3}\right) \cdot{ }^{51}$ The process consisted of an enantioselective domino cycloisomerization/hetero-DielsAlder reaction of $\alpha$-keto ester $\mathbf{1 7 4}$ with alkynyl alcohols 175, providing the corresponding chiral bicyclic spiroketals 176 in moderate to quantitative yields (50-99\%), low to high diastereoselectivities (34-90\% de) and high enantioselectivities (75-98\% ee) (Scheme 48). The first cycloisomerization step of the alkynyl alcohol was catalyzed by

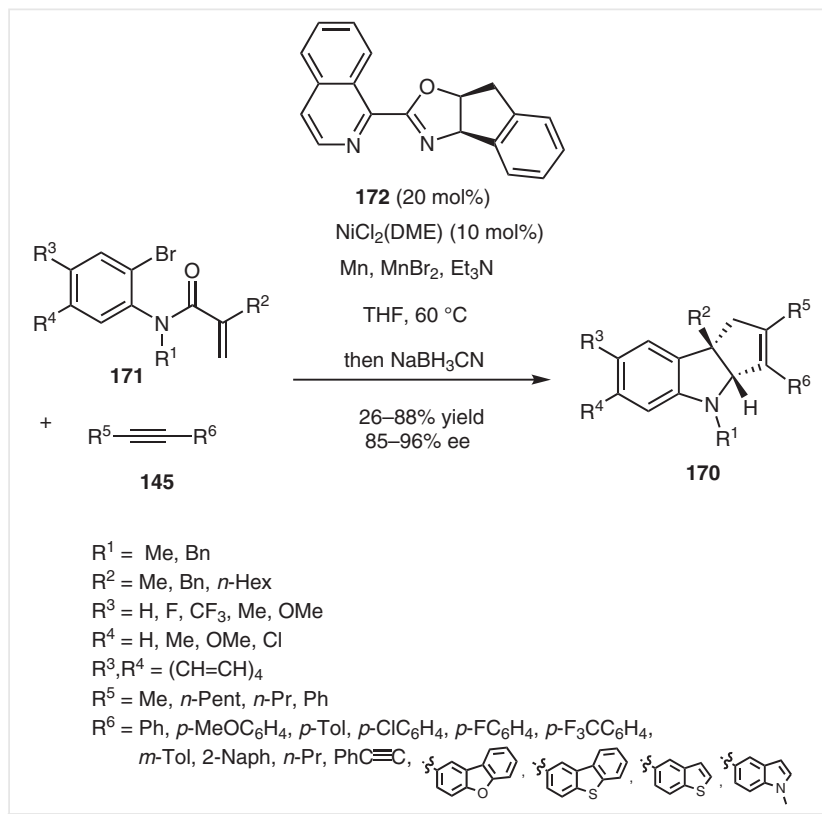

Scheme 47 Synthesis of 2,3-fused cyclopentannulated indolines through a Ni-catalyzed domino reaction

AuCl $\left(\mathrm{PPh}_{3}\right)$, leading to a five-membered intermediate, which subsequently underwent an asymmetric heteroDiels-Alder cycloaddition with $\alpha$-keto ester 174, catalyzed by the chiral nickel catalyst, to yield the final domino product 176.

\section{Conclusion}

This short review has focused on the asymmetric synthesis of carbo- and heterocycles based on the use of chiral metal catalysts to promote domino reactions, covering the literature since the beginning of 2016. It demonstrates that a wide range of densely functionalized complex chiral rings, including medicinally relevant products, can be generated through simple one-step processes. Very different metal catalysts are today employed in these fascinating reactions, spanning from cobalt, copper, iron, palladium, rhodium, silver and zirconium, to rare earth elements (scandium, yttrium) and alkaline earth metals (magnesium). Generally, excellent enantioselectivities were observed in these processes.

For example, in the field of the formation of five- and six-membered products possessing one nitrogen atom, various densely functionalized pyrrolidines have been prepared with $98-99 \%$ ee by using chiral cobalt, nickel, rhodium and silver catalysts. Enantioselectivities of 91-94\% ee have been described in the synthesis of chiral indolines through palladium and zirconium catalysis. Chiral magnesium complexes have allowed chiral spirooxindoles and spirodihydroquinolones to be prepared with enantioselec- 


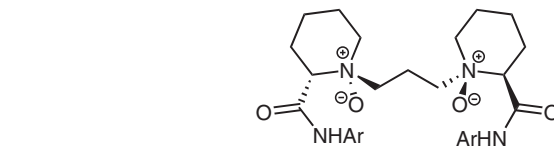

$$
\begin{aligned}
& \text { (174) } \\
& 175 \\
& \mathrm{Ar}=2,6-(i-\mathrm{Pr})_{2} \mathrm{C}_{6} \mathrm{H}_{3} \\
& 173(10 \mathrm{~mol} \%) \\
& \mathrm{Ni}\left(\mathrm{ClO}_{4}\right)_{2} \cdot 6 \mathrm{H}_{2} \mathrm{O}(10 \mathrm{~mol} \%) \\
& \mathrm{AuCl}\left(\mathrm{PPh}_{3}\right)(5 \mathrm{~mol} \%) \\
& \mathrm{CHCl}_{3}, 35^{\circ} \mathrm{C} \\
& 50-99 \% \text { yield } \\
& 34-90 \% \text { de } \\
& 75-98 \% \text { ee } \\
& \mathrm{R}^{1}, \mathrm{R}^{3}=(\mathrm{CH}=\mathrm{CH})_{2} \\
& n=1,2
\end{aligned}
$$

mechanism:
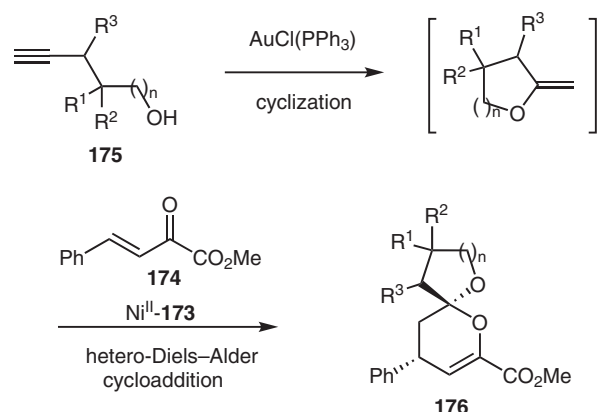

Scheme 48 Synthesis of bicyclic spiroketals through a gold- and nickelcatalyzed domino reaction

tivities of up to $97 \%$ and $98 \%$ ee, respectively. Moreover, chiral copper catalysts were used to prepare enantiopure 5,6dihydrocanthin-4-ones. In the area of the formation of fiveand six-membered products with one oxygen atom, the involvement of chiral cobalt and rhodium complexes has allowed the synthesis of functionalized chiral tetrahydrofurans to be achieved in enantioselectivities of up to $99 \%$ ee. Bicyclic furans were obtained with $86 \%$ ee by using chiral silver catalysts, while chiral 3-substituted isobenzofuranones were prepared in $92 \%$ ee by using magnesium complexes. Oxygenated six-membered products, such as chiral chromans, were synthesized through rhodium or palladium catalysis with enantioselectivities of up to $96 \%$ and $93 \%$ ee, respectively. Furthermore, chiral bicyclic $\delta$-lactones were prepared with $93 \%$ ee on the basis of a multicatalysis approach involving copper and an organocatalyst. Surprisingly, only one method for the synthesis of rings exhibiting a sulfur atom, i.e., tetrahydrothiophenes, was described on the basis of iron catalysis with up to $70 \%$ ee.

In the field of five- and six-membered rings bearing several heteroatoms, chiral oxazolines were synthesized through silver catalysis with $87 \%$ ee, along with chiral 2-alkyl-5-aminooxazoles through magnesium catalysis with 96\% ee, chiral aryl 5-bromo-1,3-oxazinan-2-ones, 3,4-dihy-
dro-2H-1,2,4-benzothiadiazine-1,1-dioxides and chiral benzimidazoles through scandium catalysis with $99 \%$, 93\% and $97 \%$ ee, respectively. Different types of enantiopure carbon rings have also been generated, such as spiropyrazolones in $99 \%$ ee by using chiral silver complexes, diquinanes with $98 \%$ ee using yttrium catalysts and functionalized cyclopentanes in $99 \%$ ee through cobalt catalysis. Six-membered carbon rings, belonging to chiral indoles and spiroindolinones, were also easily produced on the basis of zirconium and magnesium catalysis in $93 \%$ and $>99 \%$ ee, respectively. Asymmetric metal-catalyzed domino reactions were also applied to simultaneously generate two rings in the same step. For example, silver catalysts allowed chiral cis-3a,8a-hexahydropyrrolo[2,3-b]indoles and tetrahydrobenzofuro[2,3-b]pyrroles to be achieved in $90 \%$ and $87 \%$ ee, respectively. Moreover, tricyclic piperidines and spirocyclic lactams were synthesized in $87 \%$ and $97 \%$ ee from magnesium and copper chiral catalysts, respectively.

In the near future, other metal catalysts will undoubtedly be applied to the one-step syntheses of many types of chiral cyclic compounds, with efforts devoted towards the use of 'green' metals.

(1) (a) Noyori, R. Asymmetric Catalysts in Organic Synthesis; WileyVCH: New York, 1994. (b) Beller, M.; Bolm, C. Transition Metals for Organic Synthesis, Vol. I and II; Wiley-VCH: Weinheim, 1998. (c) Ojima, I. Catalytic Asymmetric Synthesis, 2nd ed; Wiley-VCH: New York, 2000. (d) Transition Metals for Organic Synthesis, 2nd ed; Beller, M.; Bolm, C., Ed.; Wiley-VCH: Weinheim, 2004. (e) Tietze, L. F.; Ila, H.; Bell, H. P. Chem. Rev. 2004, 104, 3453. (f) Ramón, D. J.; Yus, M. Chem. Rev. 2006, 106, 2126.

(2) (a) Posner, G. H. Chem. Rev. 1986, 86, 831. (b) Tietze, L. F.; Beifuss, U. Angew. Chem. Int. Ed. 1993, 32, 131. (c) Tietze, L. F. Chem. Rev. 1996, 96, 115. (d) Parsons, P. J.; Penkett, C. S.; Shell, A. J. Chem. Rev. 1996, 96, 195. (e) Ramón, D. J.; Yus, M. Angew. Chem. Int. Ed. 2005, 44, 1602. (f) Pellissier, H. Tetrahedron 2006, 62, 2143. (g) Pellissier, H. Tetrahedron 2006, 62, 1619. (h) Tietze, L. F.; Brasche, G.; Gericke, K. Domino Reactions in Organic Synthesis; Wiley-VCH: Weinheim, 2006. (i) Enders, D.; Grondal, C.; Hüttl, M. R. M. Angew. Chem. Int. Ed. 2007, 46, 1570. (j) Touré, B. B.; Hall, D. G. Chem. Rev. 2009, 109, 4439. (k) Clavier, H.; Pellissier, H. Adv. Synth. Catal. 2012, 354, 3347. (1) Pellissier, H. Adv. Synth. Catal. 2012, 354, 237. (m) Pellissier, H. Chem. Rev. 2013, 113, 442. (n) Domino Reactions: Concepts for Efficient Organic Synthesis; Tietze, L. F., Ed.; Wiley-VCH: Weinheim, 2014. (o) Pellissier, H. Adv. Synth. Catal. 2016, 358, 2194. (p) Snyder, S. A. Science of Synthesis. Applications of Domino Transformations in Organic Synthesis, Vol. 1-2; Thieme: Stuttgart, 2016. (q) Pellissier, H. Asymmetric Metal Catalysis in Enantioselective Domino Reactions; Wiley-VCH: Weinheim, 2019. (r) Pellissier, H. Adv. Synth. Catal. 2019, 361, 1733.

(3) (a) Multicomponent Reactions in Organic Synthesis; Zhu, V.; Wang, Q.; Wang, M., Ed.; Wiley-VCH: Weinheim, 2014. (b) Multicomponent Reactions: Concepts and Applications for Design and Synthesis; Herrera, R. P.; Marques-Lopez, E., Ed.; John Wiley: Hoboken, 2015 
(4) (a) Bianchi, E.; Caldwell, M. E.; Cole, J. R. J. Pharm. Sci. 1968, 57, 696. (b) Miyazawa, M.; Kasahara, H.; Kameoka, H. Phytochemistry 1996, 42, 531. (c) Jensen, B. S. CNS Drug Rev. 2002, 8, 353. (d) Marti, C.; Carreira, E. M. Eur. J. Org. Chem. 2003, 2209. (e) Lin, H.; Danishefsky, S. J. Angew. Chem. Int. Ed. 2003, 42, 36. (f) Huo, J.; Yang, S.-P.; Ding, J.; Yue, J.-M. J. Nat. Prod. 2004, 67, 1470. (g) Cho, J. Y.; Williams, P. G.; Kwon, H. C.; Jensen, P. R.; Fenical, W. J. Nat. Prod. 2007, 70, 1321. (h) Galliford, C. V.; Scheidt, K. Angew. Chem. Int. Ed. 2007, 46, 8748. (i) Hong, L.; Wang, R. Adv. Synth. Catal. 2013, 355, 1023. (j) Trost, B. M.; Bringley, D. A.; Zhang, T.; Cramer, N. J. Am. Chem. Soc. 2013, 135, 16720. (k) Yu, B.; Yu, D.-Q.; Liu, H.-M. Eur. J. Med. Chem. 2015, 97, 673. (1) Pellissier, H. Beilstein J. Org. Chem. 2018, 14, 1349. (m) Pellissier, H. Synthesis 2019, 51, 1311. (n) Dalpozzo, R.; Pellissier, H.; Chimni, S. S.; Torres, R. R. Asymmetric Synthesis of 3,3-Disubstituted Oxindoles; World Scientific Publishing Europe Ltd: London, 2019.

(5) (a) Abbiati, G.; Rossi, E. Beilstein J. Org. Chem. 2014, 10, 481. (b) Pellissier, H. Chem. Rev. 2016, 116, 14868. (c) Silver Catalysis in Organic Synthesis; Li, C.-J.; Bi, X., Ed.; Wiley-VCH: Weinheim, 2019.

(6) Li, J.-Y.; Kim, H. Y.; Oh, K. Adv. Synth. Catal. 2016, 358, 984.

(7) Kimura, M.; Matsuda, Y.; Koizumi, A.; Tokumitsu, C.; Tokoro, Y.; Fukuzawa, S.-i. Tetrahedron 2016, 72, 2666.

(8) Liu, H.-C.; Tao, H.-Y.; Cong, H.; Wang, C.-J.J. Org. Chem. 2016, 81, 3752.

(9) Bai, X.-F.; Zhang, J.; Xia, C.-G.; Xu, J.-X.; Xu, L.-W. Tetrahedron 2016, 72, 2690.

(10) (a) Pellissier, H.; Clavier, H. Chem. Rev. 2014, 114, 2775. (b) Pellissier, H. Coord. Chem. Rev. 2018, 360, 122. (c) Pellissier, $\mathrm{H}$. Enantioselective Cobalt-Catalyzed Transformations; Royal Society of Chemistry: Cambridge, 2018. (d) Cobalt Catalysis in Organic Synthesis: Methods and Reactions; Hapke, M.; Hilt, G., Ed.; Wiley-VCH: Weinheim, 2020.

(11) Yu, S.; Wu, C.; Ge, S. J. Am. Chem. Soc. 2017, 139, 6526.

(12) Zhou, Y.; Yu, L.; Chen, J.; Xu, J.; He, Z.; Shen, G.; Fan, B. Org. Lett. 2018, 20, 1291.

(13) (a) Vlaar, T.; Ruijter, E.; Orru, R. V. A. Adv. Synth. Catal. 2011, 353, 809. (b) Döndas, H. A.; de Gracia Retamosa, M.; Sansano, J. M. Organometallics 2019, 38, 1828.

(14) Liu, R.-R.; Wang, Y.-G.; Li, Y.-L.; Huang, B.-B.; Liang, R.-X.; Jia, Y.X. Angew. Chem. Int. Ed. 2017, 56, 7475.

(15) (a)Wilke, G. Angew. Chem., Int. Ed. Engl. 1988, 27, 185. (b) Montgomery, J. Angew. Chem. Int. Ed. 2004, 43, 3890. (c) Modern Organonickel Chemistry; Tamaru, Y., Ed.; Wiley-VCH: Weinheim, 2005. (d) Themed issue on Recent Advances in Organonickel Chemistry: Jamison, T. Ed. Tetrahedron 2006, 62, 7493. (e) Rosen, B. M.; Quasdorf, K. W.; Wilson, D. A.; Zhang, N.; Resmerita, A.-M.; Garg, N. K.; Percec, V. Chem. Rev. 2011, 111, 1346. (f) Ankner, T.; Cosner, C. C.; Helquist, P. Chem. Eur. J. 2013, 19, 1858. (g) Yamaguchi, J.; Muto, K.; Itami, K. Eur. J. Org. Chem. 2013, 19. (h) Tasker, S. Z.; Standley, E. A.; Jamison, T. F. Nature 2014, 509, 299. (i) Pellissier, H. Enantioselective Nickel-Catalysed Transformations; Royal Chemical Society: Cambridge, 2016.

(16) Pellissier, H. Curr. Org. Chem. 2016, 20, 234.

(17) Wang, K.; Ding, Z.; Zhou, Z.; Kong, W. J. Am. Chem. Soc. 2018, $140,12364$.

(18) Yang, J.; Ke, C.; Zhang, D.; Liu, X.; Feng, X. Org. Lett. 2018, 20 , 4536.

(19) Li, X.; Xiong, Q.; Guan, M.; Dong, S.; Liu, X.; Feng, X. Org. Lett. 2019, 21, 6096.
(20) Daniels, B. E.; Ni, J.; Reisman, S. E. Angew. Chem. Int. Ed. 2016, 55, 3398.

(21) (a) Galestokova, Z.; Sebesta, R. Eur. J. Org. Chem. 2012, 6688. (b) Pellissier, H. Curr. Org. Chem. 2018, 22, 2670.

(22) Dighe, S. U.; Mahar, R.; Shukla, S. K.; Kant, R.; Srivastava, K.; Batra, S. J. Org. Chem. 2016, 81, 4751.

(23) Pellissier, H. Org. Biomol. Chem. 2017, 15, 4750.

(24) Mao, Z.; Mo, F.; Lin, X. Synlett 2016, 27, 546.

(25) Hodik, T.; Schneider, C. Chem. Eur. J. 2018, 24, 18082.

(26) Force, G.; Lock Toy Ki, Y.; Isaac, K.; Retailleau, P.; Marinetti, A.; Betzer, J.-F. Adv. Synth. Catal. 2018, 360, 3356.

(27) Touchet, S.; Reddy Kommidi, S. S.; Gros, P. C. ChemistrySelect 2018, 3, 3939.

(28) Kannan, M.; De, P. B.; Pradhan, S.; Punniyamurthy, T. ChemistrySelect 2018, 3, 859.

(29) Miao, Y.-H.; Hua, Y.-Z.; Wang, M.-C. Org. Biomol. Chem. 2019, 17, 7172.

(30) Alamsetti, S. K.; Spanka, M.; Schneider, C. Angew. Chem. Int. Ed. 2016, 55, 2392.

(31) Tietze, L. F.; Jackenroll, S.; Ganapathy, D.; Reiner, J. R. Synlett 2016, 27, 96 .

(32) Quintard, A.; Roudier, M.; Rodriguez, J. Synthesis 2018, 50, 785.

(33) Franchino, A.; Jakubec, P.; Dixon, D. J. Org. Biomol. Chem. 2016, $14,93$.

(34) Luo, W.; Yuan, X.; Lin, L.; Zhou, P.; Liu, X.; Feng, X. M. Chem. Sci. 2016, 7, 4736.

(35) Pan, H.; Huang, H.; Liu, W.; Tian, H.; Shi, Y. Org. Lett. 2016, 18, 896.

(36) Du, P.; Zhou, H.; Sui, Y.; Liu, Q.; Zou, K. Tetrahedron 2016, 72, 1573.

(37) Xia, Y.; Lin, L.; Chang, F.; Liao, Y.; Liu, X.; Feng, X. M. Angew. Chem. Int. Ed. 2016, 55, 12228

(38) Hack, D.; Dürr, A. B.; Deckers, K.; Chauhan, P.; Seling, N.; Rübenach, L.; Mertens, L.; Raabe, G.; Schoenebeck, F.; Enders, D. Angew. Chem. Int. Ed. 2016, 55, 1797.

(39) Laugeois, M.; Ponra, S.; Ratovelomanana-Vidal, V.; Michelet, V.; Vitale, M. R. Chem. Commun. 2016, 52, 5332.

(40) Halskov, K. S.; Naesborg, L.; Tur, F.; Jørgensen, K. A. Org. Lett. 2016, 18, 2220.

(41) Meazza, M.; Rios, R. Chem. Eur. J. 2016, 22, 9923.

(42) Yao, Q.; Lin, L.; Zhang, H.; Yu, H.; Xiong, Q.; Liu, X.; Feng, X. M. Org. Chem. Front. 2017, 4, 2012.

(43) Zhang, T.; Luan, Y.-X.; Zheng, S.-J.; Peng, Q.; Ye, M. Angew. Chem. Int. Ed. 2020, 59, 7439.

(44) Mei, H.; Lin, L.; Shen, B.; Liu, X.; Feng, X. Org. Chem. Front. 2018, $5,2505$.

(45) Xu, J.; Hu, L.; Hu, H.; Ge, S.; Liu, X.; Feng, X. Org. Lett. 2019, 21, 1632.

(46) Cheng, H.; Zhang, R.; Yang, S.; Wang, M.; Zeng, X.; Xie, L.; Xie, C.; Wu, J.; Zhong, G. Adv. Synth. Catal. 2016, 358, 970

(47) Cheng, H.; Zhang, R.; Wang, M.; Zeng, X.; Xie, C. Asian J. Org. Chem. 2018, 7, 1075.

(48) Mori, K.; Isogai, R.; Kamei, Y.; Yamanaka, M.; Akiyama, T. J. Am. Chem. Soc. 2018, 140, 6203.

(49) Shu, T.; Zhao, L.; Li, S.; Chen, X.-Y.; von Essen, C.; Rissanen, K.; Enders, D. Angew. Chem. Int. Ed. 2018, 57, 10985.

(50) Ping, Y.; Wang, K.; Pan, Q.; Ding, Z.; Zhou, Z.; Guo, Y.; Kong, W. ACS Catal. 2019, 9, 7335.

(51) Li, J.; Lin, L.; Hu, B.; Lian, X.; Wang, G.; Liu, X.; Feng, X. Angew. Chem. Int. Ed. 2016, 55, 6075. 